Document downloaded from:

http://hdl.handle.net/10251/111637

This paper must be cited as:

Navarro, IJ.; Yepes, V.; Martí Albiñana, JV. (2018). Social life cycle assessment of concrete bridge decks exposed to aggressive environments. Environmental Impact Assessment Review. 72:50-63. doi:10.1016/j.eiar.2018.05.003

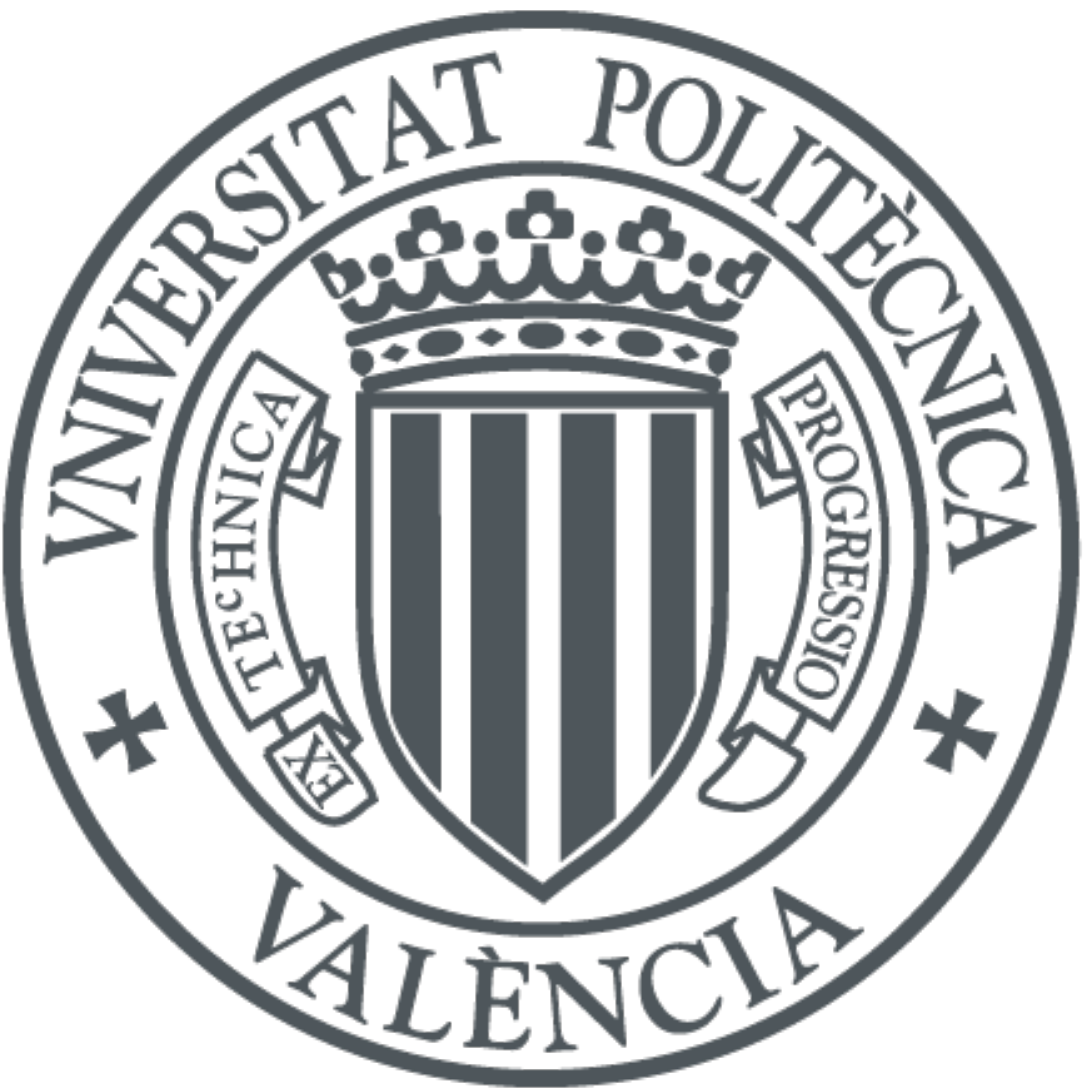

The final publication is available at

http://doi.org/10.1016/j.eiar.2018.05.003

Copyright Elsevier

Additional Information 


\title{
Social life cycle assessment of concrete bridge decks exposed to aggressive environments
}

3

4

5

\author{
Ignacio J. Navarro ${ }^{1}$ \\ Víctor Yepes ${ }^{2}$ \\ José V. Martî
}

\begin{abstract}
Sustainable design of structures includes environmental and economic aspects; social aspects throughout the life cycle of the structure, however, are not always adequately assessed. This study evaluates the social contribution of a concrete bridge deck. The social performance of the different design alternatives is estimated taking into account the impacts derived from both the construction and the maintenance phases of the infrastructure under conditions of uncertainty. Uncertain inputs related to social context are treated through Beta-PERT distributions. Maintenance needs for the different materials are estimated by means of a reliability based durability evaluation. Results show that social impacts resulting from the service life of bridges are not to be neglected in sustainability assessments of such structures. Designs that minimize maintenance operations throughout the service life, such as using stainless steel rebars or silica fume containing concretes, are socially preferable to conventional designs. The results can complement economic and environmental sustainability assessments of bridge structures.
\end{abstract}

Keywords Social Life Cycle Assessment; · Chloride corrosion; · Preventive measures; · Guidelines; · Concrete bridge; · Sustainable design .

\footnotetext{
${ }^{1}$ Graduate Research Assistant, Dept. of Construction Engineering, Universitat Politècnica de València, 46022 Valencia, Spain. E-mail: ignamar1@cam.upv.es

${ }^{2}$ Professor, Institute of Concrete Science and Technology (ICITECH), Universitat Politècnica de València, 46022 Valencia, Spain. Corresponding author. Phone +34963879563; Fax: +34963877569; E-mail: vyepesp@cst.upv.es

3 Associate Professor, Institute of Concrete Science and Technology (ICITECH), Universitat Politècnica de València, 46022 Valencia, Spain. E-mail: jvmartia@cst.upv.es
} 


\section{Introduction}

The World Commission on Environment and Development (WCED) defined in 1987 sustainable development as "meeting the needs of the present without compromising the ability of future generations to meet their needs" (WCED, 1987). Since then, sustainability has attracted an increasing attention in many sectors of the society as a response to the negative side effects of the predominant focus put on economic expansion. Sustainability has to be understood as maximizing the benefits, or minimizing the burdens, for the society, not only in the short but in the long term as well (Sierra et al., 2018). Therefore, sustainable design of a specific product should be based on the economic, social and environmental implications of its production and use over time. According to the definition of sustainable design, long lasting products are very prone to interfere in sustainable development, as their impacts will be long lasting as well, thus affecting future generations. This is the reason why essential structures, such as dams or bridges, which are designed to last for over 100 years in most of the cases, are in the spotlight of many researchers. In particular, bridges are critical elements of the transport system of a region, due to the economic and social consequences that may derive from their failure. In recent years, research has been conducted on both the environmental (Du et al., 2014; Pang et al., 2015) and the economic impacts of concrete bridges (Safi et al., 2015; Yepes et al., 2017; Navarro et al., 2018). Additionally, the simultaneous impacts in the environmental and economic field derived from the design have also been analyzed (Yepes et al., 2015; García-Segura et al., 2016; Martí et al., 2016). However, to the best of our knowledge, very little has been published regarding the social assessment of bridge structures throughout their life cycle (Gervásio and da Silva, 2013; Lounis and Daigle, 2010).

This is a natural consequence of the maturity level of the different methodologies existing for the assessment of the environmental, economic and social impacts under a life cycle framework. The environmental life cycle assessment (E-LCA) has become highly standardized both methodologically and in terms of implementation (ISO, 2006a; ISO, 2006b). The methodology existing for the assessment from an economic perspective, namely the life cycle costing (LCC), also shows a relatively mature state (Hunkeler et al., 2008), although an ISO standard does not yet exist. However, social life cycle assessment (SLCA) is a quite new technique for estimating social impacts throughout a product's life cycle. Considerable efforts have been made in SLCA for developing a strong and coherent methodology, resulting in 2009 in the 'Guidelines for social life cycle assessment of products' (UNEP/SETAC, 2009), referred herein simply as the 'Guidelines'. Nonetheless, according to Jørgensen (2013), the SLCA still requires to show its validity before it can be considered to be out of its infancy. Even the Guidelines state that 'there is an urgent need for the application of SLCA' by means of case studies that help to further develop this recently arisen methodology.

Since the publication of the Guidelines, several studies have been carried out under the life cycle framework focusing on different types of products, such as electronics (Umair et al., 2015; Wilhelm et al., 2015), food industry (De Luca et al., 2015; Bouzid and Padilla, 2014) or fertilizers (Martínez-Blanco et al., 2014). Regarding the construction sector, social impacts related to different building materials (Hosseinijou et al., 2014; Hossain et al., 2017), to concrete recycling (Hu et al., 2013) and to building construction (Dong and $\mathrm{Ng}$, 2015) has been assessed so far. These latter studies exclude the maintenance and use stage from the analysis, due to the complexity of the evaluation required for this phase. This analysis perspective may lead to erroneous conclusions, as the maintenance stage is a main source of impacts throughout the life cycle of a structure. Consequently, the comparison of different building materials under a life cycle perspective should not only take into account their different maintenance needs, but it should integrate them as well in an assessment, which considers every relevant life cycle phase of the product.

Considering the above, the application of SLCA to concrete structures taking into consideration the different life cycle stages cannot be found. In particular, no SLCA has been performed to date on bridge structures, thus evidencing a lack of information towards the sustainable design of such infrastructures. To overcome the abovementioned limitations, this study aims to apply the methodological framework proposed in the Guidelines to assess the social performance associated to different construction materials applied to a reinforced concrete bridge deck.

\section{Social performance evaluation of deck designs}


Deterioration and maintenance of reinforced concrete structures are some of the most demanding challenges that the construction industry is confronted with. In particular, concrete structures are subjected to particularly aggressive degradation processes when exposed to marine environments. Although there are several mechanisms that may degrade concrete in such environments, experience demonstrates that the most critical threat in concrete structures in marine environments is chloride-induced corrosion in the reinforcing steel. Different alternatives have been developed throughout the last years to prevent reinforcing steel from being corroded. The present research focuses on specific prevention strategies applied to a real concrete bridge deck exposed to a marine environment. The bridge of Illa de Arosa, in Galicia - Spain is analyzed. Fig. 1 shows a cross section of the bridge deck. The input data regarding both the geometry and the durability characterization of this structure has been obtained from the literature (León et al., 2013; Pérez-Fadón, 1985; Pérez-Fadón, 1986). Located $9.6 \mathrm{~m}$ over the high tide sea water level, the deck has a width of $13 \mathrm{~m}$ and a section depth of $2.3 \mathrm{~m}$. The original concrete mix of the bridge deck has a cement content of $485 \mathrm{~kg} / \mathrm{m}^{3}$, and a water/cement ratio w/c=0.45. According to Pérez-Fadón (1985), the reinforcing steel amount is $100 \mathrm{~kg} / \mathrm{m}^{3}$ of concrete, with a concrete cover of $30 \mathrm{~mm}$. This quantity does not include the steel of the prestressing tendons. It is worth noting that according to the Spanish regulations for marine environments, the deck is designed for no cracking of concrete, i.e. the concrete remains uncracked.

This study evaluates the social performance of alternative deck designs for the case study considered based on prevention strategies that are usually assumed when designing structures in marine environment. On one hand, the original concrete cover is increased to $35 \mathrm{~mm}, 45 \mathrm{~mm}$ and to $50 \mathrm{~mm}$ (measures CC35, CC45 and CC50 respectively henceforth). On the other hand, the original concrete mix is modified by adding fly ash, silica fume and polymers. Specifically, additions of $10 \%$ and $20 \%$ of fly ash (measures FA10 and FA20), $5 \%$ and $10 \%$ of silica fume (measures SF5 and SF10) and 10\% and 20\% of polymers (measures PMC10 and PMC20) are assumed. The mentioned percentages are expressed as a percentage of the cement content of the reference concrete mix design. The polymer assumed in the present study in the definition of PMC alternatives is styrene-butadiene rubber (SBR) latex, which has been widely used for such purposes (Yang et al., 2009). Both polymers, silica fume and fly ash, improve concrete durability by densification of concrete, thus hindering chloride diffusion. Another way to reduce concrete porosity is by reducing the water/cement ratio. In this study, a decrement in the water/cement ratio to $\mathrm{w} / \mathrm{c}=0.40$ and to $\mathrm{w} / \mathrm{c}=0.35$ (measures $\mathrm{W} / \mathrm{C} 40$ and $\mathrm{W} / \mathrm{C} 35$ ) has been considered. The concrete mixes corresponding to the design alternatives presented above are shown in Table 1. Additionally, it has been considered to treat the exposed deck surface with hydrophobic (measure HYDRO) and with sealant (measure SEAL) surface treatments. The replacement of the existing ordinary steel with galvanized steel (measure GALV) and with stainless steel (measure INOX) has also been considered. In summary, 15 preventive designs are evaluated as alternatives to the design of the existing bridge deck. This study compares the social performance of each of the presented preventive designs, taking into consideration the social impacts derived from the different stages of the life cycle for the described deck.

\section{Social Life Cycle Assessment}

The framework for SLCA presented in the Guidelines relies on the standardized E-LCA methodology as presented in ISO 14040 (ISO, 2006a) and ISO 14044 (ISO, 2006b). Therefore, the SLCA involves four steps, namely the goal and scope definition, inventory analysis, impact assessment, and interpretation.

\subsection{Definition of goal and scope}

\subsubsection{Goal of the study}

The main goal of the present study is to evaluate the social performance of the different design alternatives of the bridge deck exposed to a marine environment. The comparison of the results shall provide information to determine which of the analyzed alternatives is preferable in social terms. The research also aims to apply the SLCA methodology exposed in the Guidelines on a concrete structure, thus contributing with an unprecedented case study to the existing knowledge on SLCA and to the sustainable design of bridges.

\subsubsection{Functional unit}


The functional unit considered for the LCA is $1 \mathrm{~m}$ length of a bridge deck providing a terrestrial connection between the Arosa Isle and the mainland. The functional unit includes the production, installation and maintenance for a service life of 100 years as required by the Spanish Ministry of Public Works (2008). This functionality is assumed to be guaranteed by the currently existing bridge deck (reference design, called 'REF' hereafter) if a proper maintenance is carried out. Consequently, in order to make the analysis results comparable, the alternative designs shall provide the same solution not only in terms of durability, but also in terms of structural behavior. According to the mix proportions reported by León et al. (2013), the reference design has a mean compressive strength $f_{c m}$ equal to $40 \mathrm{MPa}$, and a modulus of elasticity $E_{c}$ equal to $29 \mathrm{GPa}$. As observed in Table 1, the concrete mixes considered in some of the designs evaluated here, result in greater elasticity moduli or compressive strengths. In order to make the resulting designs have the same bending strength and deformability as the reference design, the depth of the deck has been slightly modified in some of the alternatives. Considering the vertical deflection at the midspan section of the bridge as a control parameter to measure deformability, the designs presenting a stiffness greater than the one of the reference design has been modified, in particular alternatives W/C35 and those including polymers in the concrete mix, namely PMC10 and PMC20. Their stiffness has been adjusted and reduced by modifying the depth of the bridge section, thus resulting in depths of $2.1 \mathrm{~m}$ and $2.23 \mathrm{~m}$, respectively. These modified sections show the same deflection than the reference design under service loads at the midspan section of the bridge. The bending strength of the reference design is guaranteed in the aforementioned modified alternatives by increasing the applied prestressing force.

\subsubsection{System boundaries}

Whereas one of the goals of the present study is to serve for the sustainability assessment of bridge structures, and considering that the system boundaries in environmental and economic LCA are usually modelled on an attributable basis, the boundaries of the present SLCA will be established based on technical processes and life cycle stages.

The system boundary is defined from the point when the construction materials are produced in their respective production centers up to the end of the required service life. The extraction of raw materials has been excluded from the analysis, following a "gate-to-grave" approach. An exception is made for the aggregates extraction for the production of concrete. This process has been considered in the study, as it takes place at the very production site, and the social impacts derived from it are directly allocatable to this center. As a comparative SLCA, processes that are considered to be identical are cut-off (ISO, 2006b). Consequently, this study considers only those processes and stages of the life cycle that are different between alternatives are considered (Martínez-Blanco et al., 2014). The differences between designs are to be found in the materials used for the construction and repair of the structure, as well as in the number of maintenance operations required during the life cycle of the bridge. The demolition stage is assumed to have very similar social impacts between the alternatives and shall therefore be excluded from the present analysis.

The social influence of an infrastructure shall be evaluated within its particular geographical context (Sierra et al., 2017b). The present study assumes that every process in the life cycle of the analyzed design options happens in Spain, but different production locations are involved. Fig. 2 summarizes the social system and the activity locations considered in the present SLCA. It shall be noted that the social impacts derived from energy generation, as well as those related to transportation processes between the different production facilities, have been excluded from the present study.

\subsection{Inventory}

In the inventory phase of a SLCA, it is essential to identify those stakeholders affected along the life cycle of the product that is being analyzed. The selection of the different stakeholder categories and subcategories follows a top-down approach based on the methodological sheets proposed by UNEP/SETAC (2013). A hot spot analysis has been carried out to identify the relevant social concerns for the specific case study analyzed (Hosseinijou et al., 2014). This analysis is based on the evaluation of the regional development plan designed for the region of Pontevedra, as this region concentrates the greatest input to the bridge deck's life cycle (UNEP/SETAC, 2009). In particular, the SWOT (strengths, weaknesses, opportunities and threats) analysis presented in the aforementioned 
plan gives an overall picture of the social problems in the area, thus allowing to select the categories and subcategories of the present SLCA. Additionally, focusing on Pontevedra to detect the hot spots seems reasonable in this particular case since both Pontevedra and A Coruña shares a similar social context, and this context is more disadvantageous than the ones for the rest of the regions involved in the analysis.

Four main stakeholders are identified based on the development plan for Pontevedra. The first category considered in the present analysis includes the workers from the different production sites. Special emphasis is put on the problems related to gender discrimination, as well as on the high unemployment and the low salaries in the region. Additionally, due to the nature of the activities of the construction sector, the safety of the workers is also a major concern to be considered. The second category is the society and local economy, which will benefit from the economic inflows due to the production, construction and maintenance activities held in the region. The third category is the local community and the particular aesthetics of the construction site. Since tourism is a key contributor to the economy of the area, the consequences of affecting the visual perception of the area due to maintenance works are also being taken into account. At last, the fourth category is the consumers of the structure, i.e. its users. How maintenance affects the accessibility and their safety is reflected in the present SLCA. In this light, subcategories have been selected from the ones proposed by UNEP/SETAC (2013) and adapted to fit the specific social context of the region.

Based on the categories and subcategories identified above as relevant for the present study, inventory data are gathered through web research and from national statistical databases (Spanish National Statistics Institute and Spanish Tax Office database). To understand the meaning of the social context of the regions involved in the present study in relation to the rest of the regions in the Spanish territory, information has been collected as well on the minima and maxima values to be found in the Spanish regions for each of the social indicators. Table 2 shows the inventory data considered for the social assessment of the alternative bridge deck designs. It is noted that this information does not allow to evaluate the social impact of a specific activity per se, but to contextualize it (see Section 3.3.1).

Additional information is required to properly characterize the activities happening throughout the life cycle of the structure. From the existing literature and from conversations with specific material manufacturers, production performance values have been obtained for the different materials evaluated in terms of working hours per production output. Furthermore, information has been obtained regarding workers' performance. It is noted that the specific activities of the maintenance operations depend on the design considered. So, while the maintenance of the designs based on surface treatments simply consists on the periodic reapplication of this product over the surface, in the rest of the cases the concrete cover is demolished, reinforcing bars are cleaned and primed, and the cover is then regenerated with the same material as the one considered in the design evaluated. Both, the performance values regarding materials production and those related to worker activities, are shown in Table 3 . The performance values assumed in the present study, expressed as working hours per output unit (Hunkeler et al., 2008), have been gathered from both local companies involved in the production of the construction materials considered, and from official construction databases provided in Spain by regional governments. Data related to demolition and repair activities depend on the depth of the cover to be repaired. Table 3 shows demolition and repair performance values associated with $30 \mathrm{~mm}$ and $50 \mathrm{~mm}$ cover.

Information is gathered as well on unitary costs associated with the raw materials involved in the alternative designs (Navarro et al., 2018). These costs have been obtained from national construction specific price databases. Table 4 shows the unitary economic flows associated with the activities that are necessary to install a unit of the specific construction material in the bridge construction site. These economic flows are derived from the payment for the specific materials or activities. Depending on the inputs needed for the production and installation of a particular material, and considering the unitary costs associated to each of them, the economic flows can be allocated to each of the involved activities. The unitary costs associated to the inputs considered within the construction units have been obtained from national construction specific price databases. The material proportions assumed are derived from the concrete mixes presented in Table 1.

\subsection{Impact assessment}


The SLCA performed to compare the described design alternatives is based on the principles and the impact categories exposed in the Guidelines. As the present study aims to compare the social performance of different designs, the interest lies in the relative social effect of each of them rather than in the social impact itself. For such cases, the Guidelines present a methodology based on the use of Performance Reference Points, which are derived from internationally set thresholds or objectives according to best practices or particular consensus. These reference points allow the evaluation not of social impacts per se, but of social performance, namely the effect that a specific activity or product has on the social system defined in the analysis in relation to its present state. Given that every activity considered in the study takes place in Spain, the social performance of a specific activity is here estimated in relation to the Spanish average, maximum and minimum values registered in Spanish regions for specific social aspects. Based on the mentioned reference values, inventory data is normalized and transformed into subcategory indicators that range between 0 and 1 , being 1 the most desirable situation for the Spanish context.

In order to get the social performance of the alternatives for each of the considered categories, the resulting indicator values for each subcategory is aggregated, assigning a relative importance to each subcategory $p_{i}$ as shown in Eq. (1). According to Hagerty and Land (2007) where no information is available regarding the importance that people place on each subcategory, equal weighting has been considered to avoid biased results. Assuming this criterion results in the lowest level of disagreement among large variance in individuals' weightings (Hagerty and Land, 2007).

$X_{j}^{k}=\sum_{\text {subcat }} x_{i}^{k} \cdot p_{i}$

where $X_{j}^{k}$ is the unitary social performance related to impact category $j$ and activity $k$, and $x_{i k}$ is the social performance associated to activity $k$ in relation to subcategory $i$ defined in Table 5 .

The aforementioned indicators serve to characterize the social context of each of the activities held within each of the life cycle stages for each of the evaluated design alternatives, but the indicator results so as defined here are not related to the functional unit. Therefore, an activity variable is used to allocate a specific weight to the different activities assumed. The considered values of the selected activity variables are proportional to the functional unit and represent the relative importance of each of them within the analyzed system. The activity variable considered for the category Workers is the number of working hours required for each activity, and are derived from the performance values presented in Table 3. The working time, which represents the jobs created by a particular process, has been extensively used to assess social life cycle impacts in relation to stakeholder category Workers (Andrews et al., 2009; Benoît et al., 2011; Martínez-Blanco et al., 2014). The activity variable assumed for the Society category is the economic flow resulting from each activity, taking into account the values shown in Table 4. Categories Local Community and Consumer do not require such a weighting method, as the impacts affecting them happen in the same location, namely the construction site, and affect the same number of persons. However, these impacts are, so as defined in the present study, proportional to the functional unit, to the extent that they are a function of the required maintenance operations and the consequent time $\Sigma t_{m}$ that the structure is affected by them.

Once the category indicators $X_{j}^{k}$ for each of the involved production centers are calculated, the indicators are aggregated considering the described weighting system, thus resulting in a weighted category indicator $\bar{X}_{J}$ for each of the considered categories as shown in Eq. (2).

$\bar{X}_{J}=\sum_{\text {activities }} X_{j}^{k} \cdot \frac{n_{k, j}}{\sum n_{k, j}}$

where $n_{k, j}$ is the value of the activity variable associated to impact category $j$ which is involved in activity $k$.

Equal weighting is assumed to aggregate the indicators obtained for each category, namely $p_{j}$. The weighting defined for the calculation of the category indicator $\bar{X}_{J}$ allows the designer to know the relative importance that 
each activity has on the social impact of an alternative, thus providing an intermediate result to help in the decision assessment. However, this does not allow the designer to compare between alternatives, as weights have been defined in relation to each of the alternatives, and not in relation to the collection of alternatives to be compared. In order to make comparison feasible, a comparison factor $\phi_{\mathrm{j}}$ is defined for each category as shown in Eq. (3) and Eq. (4). The comparison factors are here used to reward those alternatives that contribute to better social performances in the particular category under evaluation by either creating more jobs (category Workers), creating more wealth (category Society) or reducing the time that the bridge is affected by maintenance (categories Local Community and Consumer) when compared to the rest of the alternatives. The activity variables chosen here are meant to measure the different stakeholders' interests. Consequently, these factors are obtained for a specific alternative as the ratio between the total amount of the activity variable resulting from the life cycle stage evaluated and the maximum of those amounts taking into consideration all the alternatives. The maximum value of a comparison factor is 1 , being this the case of the most desirable alternative in terms of the specific activity variable considered.

$\phi_{j}=\frac{\sum n_{k, j}}{\left(\sum n_{k, j}\right)_{\max }}$

Where the most desirable alternative is the one that minimizes the value of the activity variable, as in the case of the categories Local Community and Consumer, the comparison factor is defined as:

$\phi_{j}=\frac{\left(\sum n_{k, j}\right)_{\min }}{\sum n_{k, j}}$

Considering the above, social performance $I_{m}$ is obtained for each of the defined life cycle stages $m$ as shown in Eq. (5). As mentioned in the inventory phase, two main stages have been considered in the comparison of design, namely the construction and the maintenance stage, assuming that each of these includes every extraction and material production activity described in the inventory.

$I_{m}=\sum_{c a t} \bar{X}_{j} \cdot p_{j} \cdot \phi_{j}$

A simple addition is performed between the impacts resulting from each life cycle stage to get the social performance score $I_{L C A}$ of an alternative throughout its entire life cycle, as shown in Eq. (6). It shall be noted that categories Local Community and Consumer are only considered in the evaluation of the social performance during the maintenance stage of the life cycle. This is because the impacts on these stakeholders are the same during the construction stage and have been therefore excluded (Section 3.1.3).

$I_{L C A}=\sum I_{m}$

\subsubsection{Service Life prediction and maintenance strategies}

A reliability-based service life prediction is assumed to evaluate when maintenance operations shall be held. In the present study, the chloride-induced corrosion of the deck steel reinforcement is considered to affect reliability, so that the bridge condition is guaranteed if the chloride concentration at the reinforcing bars is below the critical content. The critical chloride content $C_{\text {crit }}$ is the concentration of chlorides needed to start the corrosion and depends on the properties of steel. Here, it is accepted that maintenance operations take place before the critical chloride content is reached, so that the steel rebars are not affected by corrosion when maintenance is carried out.

The chloride concentration at the reinforcement $C(r, t)$ is predicted on the basis of the fickean model suggested in Fib Bulletin 34 (Fib, 2006). This model has been modified to take into account the scenario where a reinforcing bar is simultaneously exposed to two advancing chloride fronts, the so-called corner effect (Titi and Biondini, 2016). So, the chloride concentration to be expected in the concrete cover at a specific depth in both $x$ and $y$ directions, and in a particular time $t$ is expressed as: 
$1 \quad C(x, y, t)=C_{0}+\left(C_{s}-C_{0}\right) \cdot\left(1-\operatorname{erf} \frac{x}{2 \sqrt{D_{0, x} \cdot\left(\frac{t_{0}}{t}\right)^{\alpha} \cdot t}} \cdot \operatorname{erf} \frac{y}{2 \sqrt{D_{0, y} \cdot\left(\frac{t_{0}}{t}\right)^{\alpha} \cdot t}}\right)$

where $C(x, y, t)$ is the chloride concentration (wt.\%/binder) at concrete depth $[x, y](\mathrm{mm})$ and time $t$ (years); $C_{s}$ is the chloride concentration at the surface of the concrete (wt.\%/binder); $C_{0}$ is the initial chloride content of the concrete (wt.\%/binder), assumed here to be zero; $\operatorname{erf}\left(\right.$.) is the Gauss error function; $D_{0}$ is the non-steady state chloride migration coefficient ( $\mathrm{mm}^{2} /$ years). It has been assumed that the concrete is homogeneous and that the chloride diffusion coefficient is the same in both directions $\left(D_{0, x}=D_{0, y}\right)$. A value of 0.5 has been assumed for the age factor $\alpha$, as proposed in the Spanish concrete design code (Spanish Ministry of Public Works, 2008). As reference time, $t_{0}=0.0767$ years (namely 28 days) has been considered. The concrete cover in the $y$-direction $\left(r_{y}\right)$ is assumed constant and equal to $50 \mathrm{~mm}$ for every design analyzed, while the cover in the $x$-direction $\left(r_{x}\right)$ is assumed to vary depending on the prevention alternative studied.

The service life of the concrete bridge deck is then evaluated taking into account a reliability index $\beta$, which results from evaluating the inverse of the Gaussian cumulated distribution function of the probability of failure $p_{f}$. The reliability-based maintenance has been optimized by finding the specific maintenance interval $T_{\text {opt }}$ that maximizes the life cycle social performance of the structure, while ensuring that the minimum required reliability index $\beta_{\text {lim }}$ is not exceeded. According to Nogueira et al. (2012), a target reliability index $\beta_{\text {lim }}$ of 1.30 is assumed. It shall be noted that the reliability index $\beta(t)$ of the structure at a specific time depends on the advance of the deterioration process at this time. This study assumes that those maintenance operations where concrete cover is demolished and regenerated only affect the depth where the chloride concentration exceeds the critical chloride content, so that the social impacts associated to maintenance activities depend on the maintenance interval evaluated.

In the present study, durability characterization parameters for each material have been obtained from the existing literature. Table 6 shows the statistical values of the diffusion coefficient $D_{o}$ and of the critical chloride $C_{\text {crit }}$ content assumed for the different designs, as well as the resulting mean time to failure for each of them in years. Considering the existing distance between the structure and the sea water surface, a surface chloride content of $C_{s, 0}=3.34 \%$ is assumed for the evaluation of the bridge deck.

\subsubsection{Uncertainties}

In order to deal with the uncertainty associated to the social context during the maintenance phase, a distribution function is chosen based on the most likely value, as well as the minimum and maximum values that the considered social parameters might adopt in the future (Sierra et al., 2017a). Consequently, a Beta distribution is assigned in the present study to the inventory data. The distribution used is based on the PERT technique, also known as Beta-PERT distribution. Let $x_{\max }, x_{\bmod }$ and $x_{\min }$ be the three values defining the maximum, the most probable and the minimum values of each uncertain variable. These values are derived from the analysis of the historical series consulted in the National Statistics Institute in Spain and are shown in Table 7. So, the parameters $\alpha$ and $\beta$ of the Beta-Pert distribution are obtained as:

$$
\begin{aligned}
& \alpha=\frac{2 \cdot\left(x_{\max }+4 \cdot x_{\bmod }-5 \cdot x_{\min }\right)}{3 \cdot\left(x_{\max }-x_{\min }\right)} \cdot\left[1+4 \cdot \frac{\left(x_{\bmod }-x_{\min }\right) \cdot\left(x_{\max }-x_{\bmod }\right)}{\left(x_{\max }-x_{\min }\right)^{2}}\right] \\
& \beta=\frac{2 \cdot\left(5 \cdot x_{\max }-4 \cdot x_{\bmod }-x_{\min }\right)}{3 \cdot\left(x_{\max }-x_{\min }\right)} \cdot\left[1+4 \cdot \frac{\left(x_{\bmod }-x_{\min }\right) \cdot\left(x_{\max }-x_{\bmod }\right)}{\left(x_{\max }-x_{\min }\right)^{2}}\right]
\end{aligned}
$$

It has been shown that results converge with 6000 iterations.

\subsection{Results and interpretation}

The SLCA based on the methodology presented above results in the use of stainless steel being the most socially preferable design alternative for the case study evaluated, followed by the designs based on the addition of silica fume and polymers. Table 8 shows the social life cycle performance results $I_{L C A}$ for the alternative designs considered, including as well the partial impact scores $I_{m}$ derived from the construction and the maintenance life 
cycle phases. It shall be derived that the social impacts resulting from the construction stage and those derived from the maintenance phase are both equally contributing to the final score, which is in line with the results of previous studies in the field of SLCA applied to bridges (Gervásio and da Silva, 2013; Soliman and Frangopol, 2014). Although in some cases the impacts of maintenance are even higher than those of construction, it is concluded that, in general, impacts arising from construction are 5 to $15 \%$ higher.

As mentioned above, construction stage is considered here to affect only two main stakeholders, namely the workers and the local economies involved in the production and construction processes. Fig. 3 shows the performance results during this stage for the evaluated alternatives, as well as the percentage that each concept represents of the total. Regarding the impact category Workers, it is observed that the social performance is very similar between alternatives. This is mainly because the activity that comprises the most of the workers' activity variable is the construction itself, being this process very similar between the different designs. The slight differences observed are due to the material production processes. It is worth noting that the alternatives with a greater affection to this category are those involving very specialized materials, such as stainless steel and polymer-modified concrete, as those processes require greater work force. This positive impact is partially diminished because the production centers associated with these materials are located in very desirable social contexts as derived from Table 2, thus not contributing to regional equity. In general, it is shown that the relevance of the category Workers in this stage takes up to $60-65 \%$ of the performance result of every alternative. However, it is observed that those alternatives based on specialized and consequently more expensive materials result in greater social impact. This is a consequence of the greater impact of these alternatives on the local economies derived from greater economic flows to the production centers. In those cases, the relative importance of the category Society takes up to $54-57 \%$ of the total performance result. Consequently, the alternatives that show a better social performance during the construction stage are based on the use of those materials, namely stainless and galvanized steel, as well as polymer-modified concrete.

During the maintenance stage, the most desirable designs in social terms are by far those based on the use of stainless steel and the addition of silica fume. Both of them are alternatives with a high durability that require no or very little maintenance. Therefore, the accessibility and the safety conditions for the users, as well as the site aesthetics, remain almost unaffected by maintenance operations. Additionally, local people are not affected by noise or pollutants emitted during those activities. This fact results in very high performance results associated to Consumers and Local Community categories. The social performance on workers and local economies are, however, almost nil. Fig.4 shows the results associated to the maintenance stage of the bridge, as well as the percentage that each concept represents of the total.

In the rest of the alternatives, two clear trends can be observed. On the one hand, alternatives that are less durable and consequently demand more maintenance have a great impact on categories Workers and Society, derived from the production of materials and the repair activities to be held. In those cases, social performance on Consumers and Local Community is almost non-existent. This is the case of alternatives such as the reference design (REF) or those based on the increase of the concrete cover. On the other hand, alternatives with a greater durability, such as W/C35 or PMC20, show exactly an opposite composition of the resulting social performance, mainly based on the positive affection to the local community and infrastructure users. Alternatives based on surface treatments, which are very maintenance demanding, show the same performance behavior, as these maintenance activities are carried out particularly fast.

Fig. 5 shows the life cycle performance scores $I_{L C A}$ of each alternative, as well as the contribution of the construction and the service stage on the final score. Based on the assumptions considered in this study, the use of stainless steel reinforcement (INOX) has resulted in the greatest social impact, followed by the alternatives based on the addition of silica fume SF10 and the use of polymer modified concrete PMC20. All of them are alternatives with high durability, which result in low maintenance. In Fig. 5 it can be observed that two alternatives, such as the reference design and PMC10, which are opposite in durability and service life performance, result in very similar social results. This is due to the fact that in the present study the same weight is assigned to every stakeholder, and they benefit from either the presence (Workers, Society) or the absence of maintenance (Consumers, Local Community). In order to understand the effect of considering different weighting factors, two alternative weighting scenarios are tested to evaluate the sensitivity of the results, where greater importance (30\%) 
is assigned either to stakeholders Workers and Society or to Consumers and Local Community. Table 9 shows the social performance results for the different scenarios assumed. According to the sensitivity analysis, it is found that the results of the assessment do not vary significantly with smaller changes in the assumed weighting factors. Consequently, the equal weighting of the categories is shown to be an appropriate and reliable method for the present case study.

An additional sensitivity analysis is performed in order to show how giving preference to each of the stakeholders affects the results of the assessment. Four additional scenarios are considered, each of them gives a significant importance to one of the stakeholder groups (40\%), while leaving the weights of the rest of the group to $20 \%$. Fig. 6 shows the obtained social scores $I_{L C A}$ under the different scenarios for the six alternatives that reached the highest social scores in the egalitarian scenario, namely alternatives INOX, SF10, PMC10, PMC20, GALV and REF. These are the six alternatives with the highest scores in the four new scenarios evaluated as well. Fig. 6 also shows the weights assumed for each of the evaluated scenarios.

It is observed that the alternative INOX is socially preferable under every scenario, and with a wide margin compared to the other alternatives. Regarding the second alternative, SF10, it is preferable both in the egalitarian scenario and in those that give more importance to the users and the local community. When greater weight is associated to either workers or society categories, PMC20 alternative is preferable over SF10. This is mainly due to the fact that SF10 alternative generates lesser economic flow towards the involved production centers and demands lesser working hours for the production of the construction materials when compared to PMC20 alternative.

\section{Conclusions}

Social Life Cycle Assessment is a new technique still under development in order to serve for the sustainability assessment. As there is no commonly agreed methodology available thus far, the application of SLCA to real case studies is highly recommended according to the Guidelines to further develop this tool. In this study, 15 different preventive designs for a concrete bridge deck is carried out in accordance with the four-step assessment structure proposed in the Guidelines. As one of the first attempts of social assessment of a bridge structure under a life cycle perspective, the developed model provides a comprehensive framework to be used by designers in order to evaluate the social performance of different construction materials. The methodology developed allows for the evaluation of a single life cycle indicator, taking into account the uncertainties associated both to maintenance activities as well as on the social context expected throughout the life cycle of the structure.

A reliability based maintenance optimization is performed for the designs under evaluation. Considering an equally weighting system, it has been shown that the social benefits resulting from maintenance-free solutions are considerably greater than those derived from maintenance demanding designs. A sensitivity analysis on the weighting system has served to confirm this conclusion when small changes in the assigned weights are assumed.

The analysis has shown that the use of stainless steel reinforcement performs socially the best for the case study evaluated, as well as those designs based on silica fume and polymer additions to concrete. The results obtained in the present study have brought to light that social impacts derived from maintenance play a major role in the sustainability performance of a structure. As for future lines of research, it would be interesting to integrate the social assessment methodology presented into the environmental and economic life cycle assessment of bridges, in order to produce a comprehensive sustainability analysis of such long lasting structures. 
The authors acknowledge the financial support of the Spanish Ministry of Economy and Competitiveness, along with FEDER funding (Project: BIA2017-85098-R).

\section{References}

Andrews, E., Lesage, P., Benoît, C., Parent, J., Norris, G., Revéret, J. P., 2009. Life cycle attribute assessmentcase study of Quebec tomatoes. J. Ind. Ecol. 13(4), 565-578. https://dx.doi.org/10.1111/j.15309290.2009.00142.x.

Benoît-Norris, C., Vickery-Niederman, G., Valdivia, S., Franze, J., Traverso, M., Ciroth, A., Mazijn, B., 2011. Introducing the UNEP/SETAC methodological sheets for subcategories of social LCA. Int. J. Life Cycle Assess. 16 (7), 682e690. https://dx.doi.org/10.1007/s11367-011-0301-y.

Bertolini, L., Bolzoni, F., Pastore, T., Pedeferri, P., 1996. Behaviour of stainless steel in simulated concrete pore solution. Br. Corros. J. 31, 218-22. https://dx.doi.org/doi:10.1179/000705996798114572.

Bouzid, A., Padilla, M., 2014. Analysis of social performance of the industrial tomatoes food chain in Algeria. New Medit. 1, 60-65.

Cheewaket, T., Jaturapitakkul, C., Chalee, W., 2014. Concrete durability presented by acceptable chloride level and chloride diffusion coefficient in concrete: 10-year results in marine site. Mater. Struct. 47, 1501-11. https://dx.doi.org/10.1617/s11527-013-0131-4.

Darwin, D., Browning, J., O’Reilly, M., Xing, L., Ji, J., 2009. Critical Chloride Corrosion Threshold of Galvanized Reinforcing Bars. ACI Mater. J. 106, 176-83. https://dx.doi.org/10.14359/56465.

De Luca, A. I., Iofrida, N., Strano, A., Falcone, G., Gulisano, G., 2015. Social life cycle assessment and participatory approaches: a methodological proposal applied to citrus farming in Southern Italy. Integr. Environ. Assess. Manag. 11 (3), 383-396. https://dx.doi.org/10.1002/ieam.1611.

Dette, G., Sigrist, V., 2011. Performance indicators for concrete bridges. fib Symposium proceedings. Prague. ISBN: 978-80-87158-29-6.

Dong, Y. H., Ng, S. T., 2015. A social life cycle assessment model for building construction in Hong Kong. Int. J. Life Cycle Assess. 20, 1166-1180. https://dx.doi.org/10.1007/s11367-015-0908-5.

Du, G., Safi, M., Pettersson, L., Karoumi, R., 2014. Life cycle assessment as a decision support tool for bridge procurement: environmental impact comparison among five bridge designs. Int. J. Life-cycle Assess. 19(12), 1948-1964. https://dx.doi.org/10.1007/s11367-014-0797-z.

European Institute for Gender Equality, 2015. Gender Equality Index 2015 - Measuring gender equality in the European Union 2005-2012. https://dx.doi.org/10.2839/770576.

Fib. Fib Bulletin 34, 2006. Model code for service life design. Lausanne: Fib.

Frederiksen, J. M., 2000. Chloride threshold values for service life design. Second International RILEM Workshop on Testing and Modelling the Chloride Ingress into Concrete: Paris, France, 11-12 September 2000. RILEM Publications.

García-Segura, T., Yepes, V., 2016. Multiobjective optimization of post-tensioned concrete box-girder road bridges considering cost, $\mathrm{CO}_{2}$ emissions, and safety. Eng. Struct. 125, 325-336. https://dx.doi.org/10.1016/j.engstruct.2016.07.012.

Gervásio, H., da Silva, L.S., 2013. Life-cycle social analysis of motorway bridges. Struct. Infrastruct. Eng. 9, 1019-39. https://dx.doi.org/10.1080/15732479.2011.654124. 
Hagerty, M.R., Land, K. C., 2007. Constructing Summary Indices of Quality of Life: A Model for the Effect of Heterogeneous Importance Weights, Sociol. Methods Res. 35, 455-496. https://dx.doi.org/10.1177/0049124106292354.

Hossain, U., Poon, C. S., Dong, Y. H., Lo, I., Cheng, J., 2017. Development of social sustainability assessment method and a comparative case study on assessing recycled construction materials. Int. J. Life Cycle Assess. https://dx.doi.org/10.1007/s11367-017-1373-0.

Hosseinijou, S. A., Mansour, S., Shirazi, M. A., 2014. Social life cycle assessment for material selection: a case study of building materials. Int. J. Life Cycle Assess. 19, 620-645. https://dx.doi.org/10.1007/s11367013-0658-1.

Hu, M., Kleijn, R., Bozhilova-Kisheva, K. P., Di Maio, F., 2013. An approach to LCSA: the case of concrete recycling. Int. J. Life Cycle Assess. 18, 1793-1803. https://dx.doi.org/10.1007/s11367-013-0599-8.

Hunkeler, D., Lichtenvort, K., Rebitzer, G., Ciroth, A., Huppes, G., Klöpffer, W., Rüdenauer, I., Steen, B., Swarr, T., 2008. Environmental life cycle costing. SETAC Publications, Brussels. ISBN: 9781420054705

ISO (2006a) Environmental management:- life cycle assessment- principles and framework. International Standards Organization, ISO 14040: 2006, Geneva.

ISO (2006b) Environmental management—life cycle assessment— requirements and guidelines. International Organisation for Standardisation, ISO 14044:2006, Geneva.

Jørgensen, A., 2013. Social LCA—a way ahead? Int. J. Life Cycle Assess. 18, 296-299. httpss:// dx.doi.org/10.1007/s11367-012-0517-5

León, J., Prieto, F., Rodríguez, F., 2013. Proyecto de rehabilitación del puente de la Isla de Arosa. Hormig. Acero 270: 75-89.

Lounis, Z., Daigle, L., 2010. Towards sustainable design of highway bridges. National Research Council of Canada. https://dx.doi.org/ 10.1201/b10430-178.

Martí, J.V., García-Segura, T., Yepes, V., 2016. Structural design of precast-prestressed concrete U-beam road bridges based on embodied energy. J. Clean. Prod. 120, 231-240. httpss://dx.doi.org/10.1016/j.jclepro.2016.02.024.

Martínez-Blanco, J., Lehmann, A., Muñoz, P., Antón, A., Traverso, M., Rieradevall, J., Finkbeiner, M., 2014. Application challenges for the social life cycle assessment of fertilizers within life cycle sustainability assessment. J. Clean. Prod. 69, 34-48. https://dx.doi.org/10.1016/j.jclepro.2014.01.044.

Medeiros, M., Castro-Borges, P., Aleixo, D., Quarcioni, V.A., Marcondes, C., Helene, P., 2012. Reducing water and chloride penetration through silicate treatments for concrete as a mean to control corrosion kinetics. Int. J. Electrochem. Sci. 7, 9682-9696. httpss://dx.doi.org/10.1016/S0950-0618(00)00043-X.

Navarro, I.J., Yepes, V., Martí, J.V., 2018. Life Cycle Cost Assessment of preventive strategies applied to prestressed concrete bridges exposed to chlorides. Sustainability, 10, 845. https://dx.doi.org/ $10.3390 / \mathrm{su} 10030845$.

Nogueira, C.G., Leonel, E.D., Coda, H.B., 2012. Reliability algorithms applied to reinforced concrete structures durability assessment. Rev. IBRACON Estrut. Mater. 5, 440-50. https://dx.doi.org/10.1590/S198341952012000400003.

Nokken, M., Boddy, A., Hooton, R.D., Thomas, M.D.A., 2006. Time dependent diffusion in concrete-three laboratory studies. Cem. Concr. Res. 36, 200-7. httpss://dx.doi.org/10.1016/j.cemconres.2004.03.030. 
OECD (2008) Handbook on constructing composite indicators: Methodology and user guide. OECD Publications, Paris, France. ISBN: 978-92-64-04345-9.

Ohama, Y., 1995. Handbook of Polymer-Modified Concrete and Mortars. William Andrew. ISBN: 9780815513582.

Otsuki, N., Nishida, T., Yi, C., Nagata, T., 2014. Effect of blast furnace slag powder and fly ash on durability of concrete mixed with seawater. 4th International Conference on the durability of concrete structures, 24-26 July 2014. Purdue University, West Lafayette, In, USA.

Ozturk, O., Ozbay, K., Yang, H., Bartin, B., 2013. Crash Frequency Modeling for Highway Construction Zones. Transportation Research Board's 92nd Annual Meeting, Washington, D.C.

Pang, B., Yang, P., Wang, Y., 2015. Life cycle environmental impact assessment of a bridge with different strengthening schemes. Int. J. Life. Cycle Assess. 20, 1300. https://dx.doi.org/10.1007/s11367-015-09361.

Pérez-Fadón, S., 1985. Puente a la Isla de Arosa. Hormigón y Acero 157, 197-218.

Pérez-Fadón, S., 1986. Puente sobre la Ría de Arosa. Revista de Obras Públicas. January 1986, 1-16.

Safi, M., Sundquist, H., Karoumi, R., 2015. Cost-efficient procurement of bridge infrastructures by incorporating life-cycle cost analysis with bridge management systems. J. Bridg. Eng. 20. https://dx.doi.org/10.1061/(ASCE)BE.1943-5592.0000673.

Sierra, L. A., Pellicer, E., Yepes, V., 2017a. Assessing the social sustainability contribution of an infrastructure project under conditions of uncertainty. Environ. Impact Assess. Rev. 67, 61-72. https://doi.org/10.1016/j.eiar.2017.08.003.

Sierra, L. A., Pellicer, E., Yepes, V., 2017b. Method for estimating the social sustainability of infrastructure projects. Environ. Impact Assess. Rev. 65, 41-53. https://dx.doi.org/10.1016/j.eiar.2017.02.004.

Sierra, L. A., Yepes, V., Pellicer, E., 2018. A review of multi-criteria assessment of the social sustainability of infrastructures. J. Clean. Prod. 187, 496-513. httpss://dx.doi.org/ 10.1016/j.jclepro.2018.03.022.

Soliman, M., Frangopol, D. M., 2014. Life-cycle cost evaluation of conventional and corrosion-resistant steel for bridges. J. Bridge Eng. 20 (1). https://dx.doi.org/10.1061/(ASCE)BE.1943-5592.0000647.

Spanish Ministry of Public Works, 2008. EHE-08 Instrucción del Hormigón Estructural. ISBN: 978-84-498-08999.

Titi, A., Biondini, F., 2016. On the accuracy of diffusion models for life-cycle assessment of concrete structures. Struct. Infrastruct. Eng. 12, 1202-15. httpss://dx.doi.org/10.1080/15732479.2015.1099110.

Umair, S., Björklund, A., Ekener-Petersen, E., 2015. Social impact assessment of informal recycling of electronic ICT waste in Pakistan using SETAC SETAC guidelines. Resour. Conserv. Recycl. 95, 46-57. https://dx.doi.org/10.1016/j.resconrec.2014.11.008.

UNEP/SETAC, 2009. Guidelines for social life cycle assessment of products, United Nations Environment Program, Paris SETAC Life Cycle Initiative United Nations Environment Programme.

UNEP/SETAC, 2013. The methodological sheets for subcategories in social life cycle assessment (S-LCA). UNEP-SETAC Life-Cycle Initiative, Paris, France.

Vedalakshmi, R., Saraswathy, V., Song, H.W., Palaniswamy, N., 2009. Determination of diffusion coefficient of chloride in concrete using Warburg diffusion coefficient. Corros. Sci. 51 (6), 1299-1307 https://dx.doi.org/10.1016/j.corsci.2009.03.017. 
WCED—World Commission on Environment and Development, 1987. Our common future. Oxford University Press, Oxford. ISBN: 9780192820808.

3 Wilhelm, M., Hutchins, M., Mars, C., Benoit-Norris, C., 2015. An overview of social impacts and their corresponding improvement implications: a mobile phone case study. J. Clean. Prod. 102, 302-315. https://dx.doi.org/10.1016/j.jclepro.2015.04.025

Xi, Y., Bažant, Z.P., 1999. Modeling Chloride Penetration in Saturated Concrete. J. Mater. Civ. Eng. 11, 58-65. https://dx.doi.org/10.1061/(ASCE)0899-1561(1999)11:1(58)

Yang, Z., Shi, X., Creighton, A.T., Peterson, M.M., 2009. Effect of styrene-butadiene rubber latex on the chloride permeability and microstructure of Portland cement mortar. Constr. Build. Mater. 23, 2283-90. https://dx.doi.org/10.1016/j.conbuildmat.2008.11.011.

Yepes, V., Martí, J.V., García-Segura, T., 2015. Cost and CO2 emission optimization of precast-prestressed concrete U-beam road bridges by a hybrid glowworm swarm algorithm. Autom. Constr. 49, 123-134. https://dx.doi.org/10.1016/j.autcon.2014.10.013.

Yepes, V., Martí, J.V., García-Segura, T., González-Vidosa, F., 2017. Heuristics in optimal detailed design of precast road bridges. Arch. Civ. Mech. Eng. 17, 738-749. https://dx.doi.org/10.1016/j.acme.2017.02.006

Zhang, J.Z., Buenfeld, N.R., 2000. Chloride profiles in surface-treated mortar specimens. Constr. Build. Mater. 14, 359-64. https://dx.doi.org/10.1016/S0950-0618(00)00043-X. 
j $\quad$ - Index representing impact category

i - Index representing impact subcategory

$\mathrm{k} \quad$ - Index representing the different activities considered

$\mathrm{m} \quad$ - Index representing the life cycle stages

$x_{i}^{k} \quad$ - Social performance associated to activity $\mathrm{k}$ in relation to subcategory $\mathrm{i}$

$X_{j}^{k} \quad$ - Unitary social performance related to impact category $\mathrm{j}$ and activity $\mathrm{k}$

$\mathrm{n}_{\mathrm{k}, \mathrm{j}} \quad$ - Value of the activity variable associated to impact category $\mathrm{j}$ which is involved in activity $\mathrm{k}$

$\bar{X}_{J} \quad$ - Weighted category indicator

$\phi_{j} \quad$ - Comparison factor

$\mathrm{I}_{\mathrm{m}} \quad$ - Social performance for the life cycle stage $\mathrm{m}$

$\mathrm{I}_{\mathrm{LCA}}$ - Social life cycle performance results

$\mathrm{C}_{\text {crit }}$ - Critical chloride content (wt.\%/binder)

$\mathrm{C}_{\mathrm{s}} \quad$ - Chloride concentration at the surface of the concrete (wt.\%/binder)

$\mathrm{C}_{0} \quad$ - The initial chloride content of the concrete (wt.\%/binder)

$\mathrm{D}_{0} \quad$ - Non-steady state chloride migration coefficient ( $\mathrm{mm} 2 /$ years)

$\mathrm{r} \quad$ - Concrete cover $(\mathrm{mm})$

$\alpha \quad$ - Concrete age factor affecting the chloride diffusion coefficient

$\beta(\mathrm{t}) \quad$ - Reliability index at time $\mathrm{t}$

$\beta_{\mathrm{lim}}$ - Minimum annual reliability index required

3 APPENDIX B. List of acronyms used in the study

REF - Reference design that serves as the basis to develop the case study presented

$\mathrm{CC}$ - Concrete cover

FA - Fly ash

SF - Silica fume

PMC - Polymer modified concrete

HYDRO - Hydrophobic surface treatment

SEAL - Sealant surface treatment

GALV - Galvanized reinforcing steel

INOX - Stainless reinforcing steel 


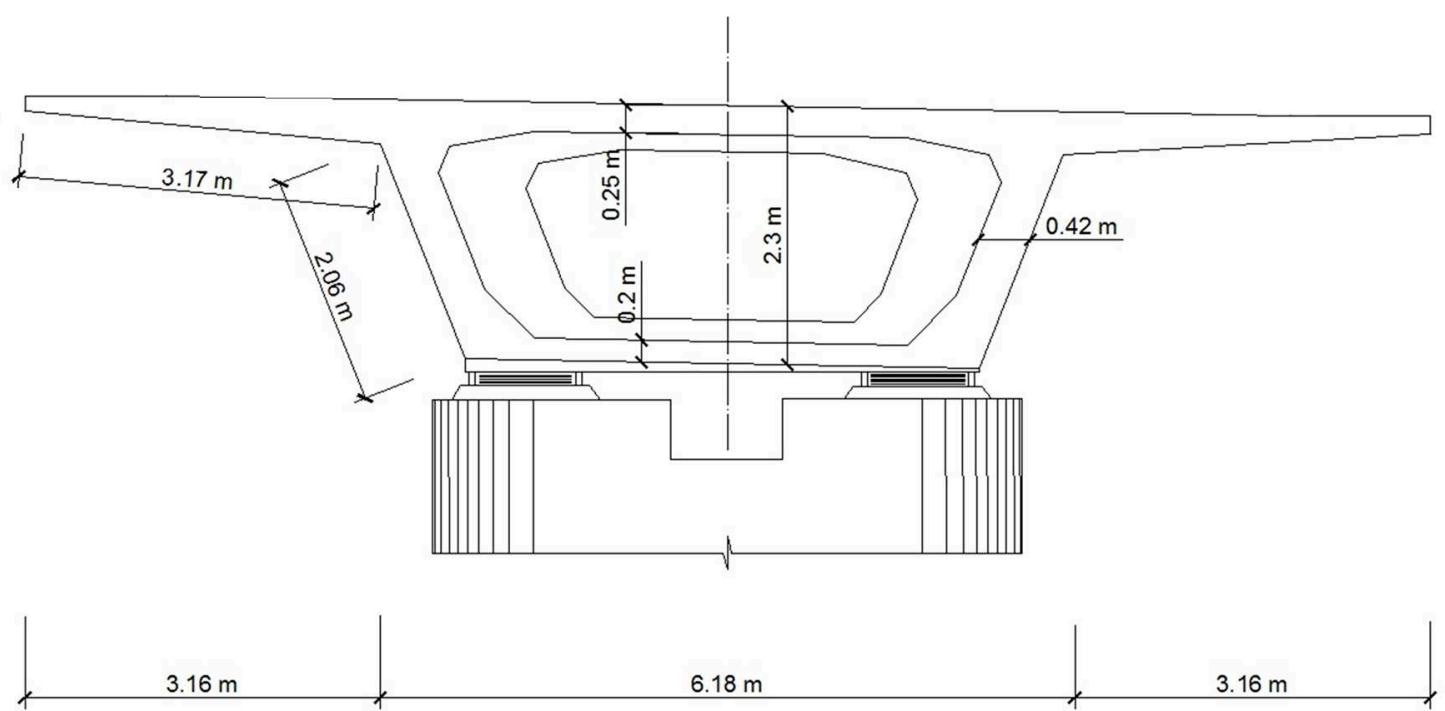

1

2 Fig. 1. Cross section of the Arosa's concrete bridge deck

3

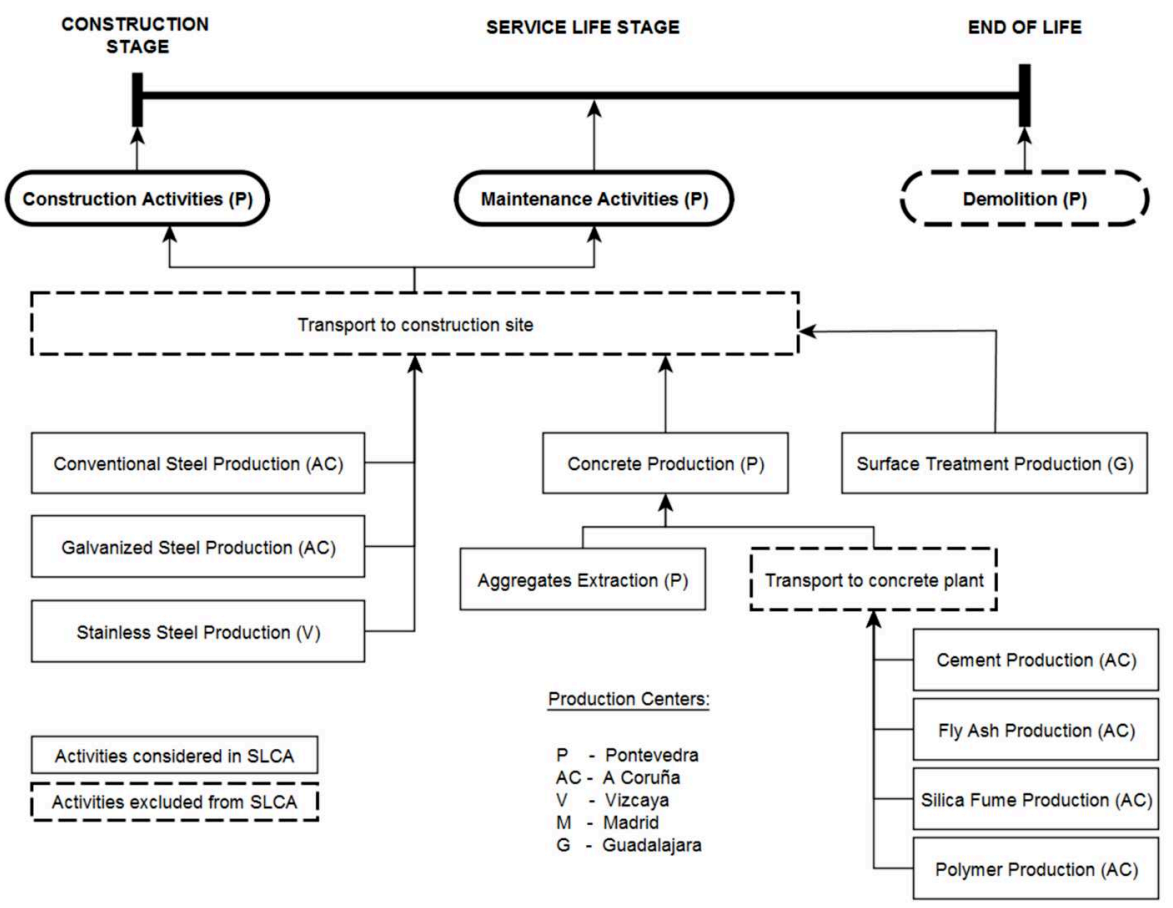

5 Fig. 2. System boundaries considered in the SLCA 


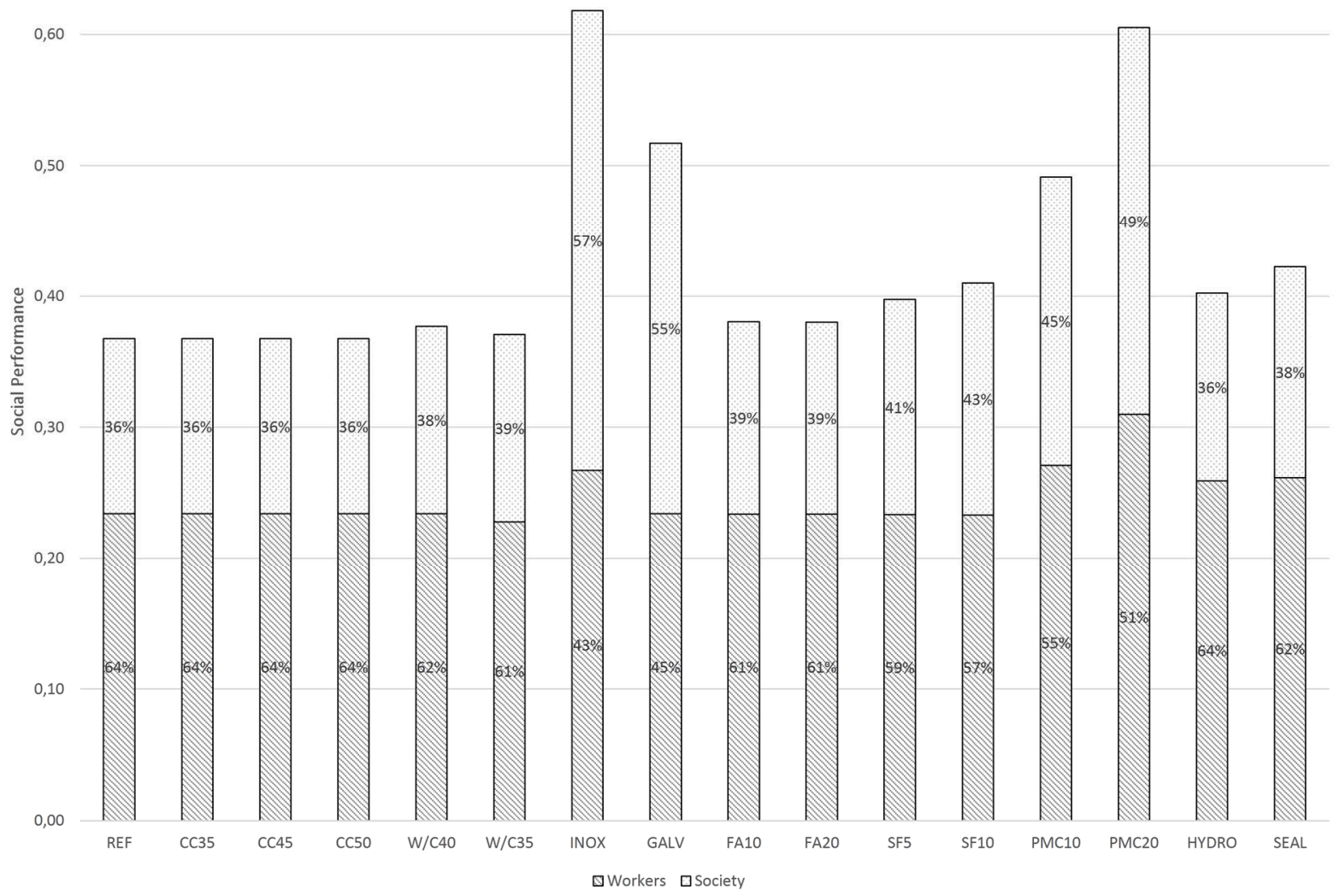

2

3 Fig. 3. Social performance of the alternative designs during the construction stage

4 


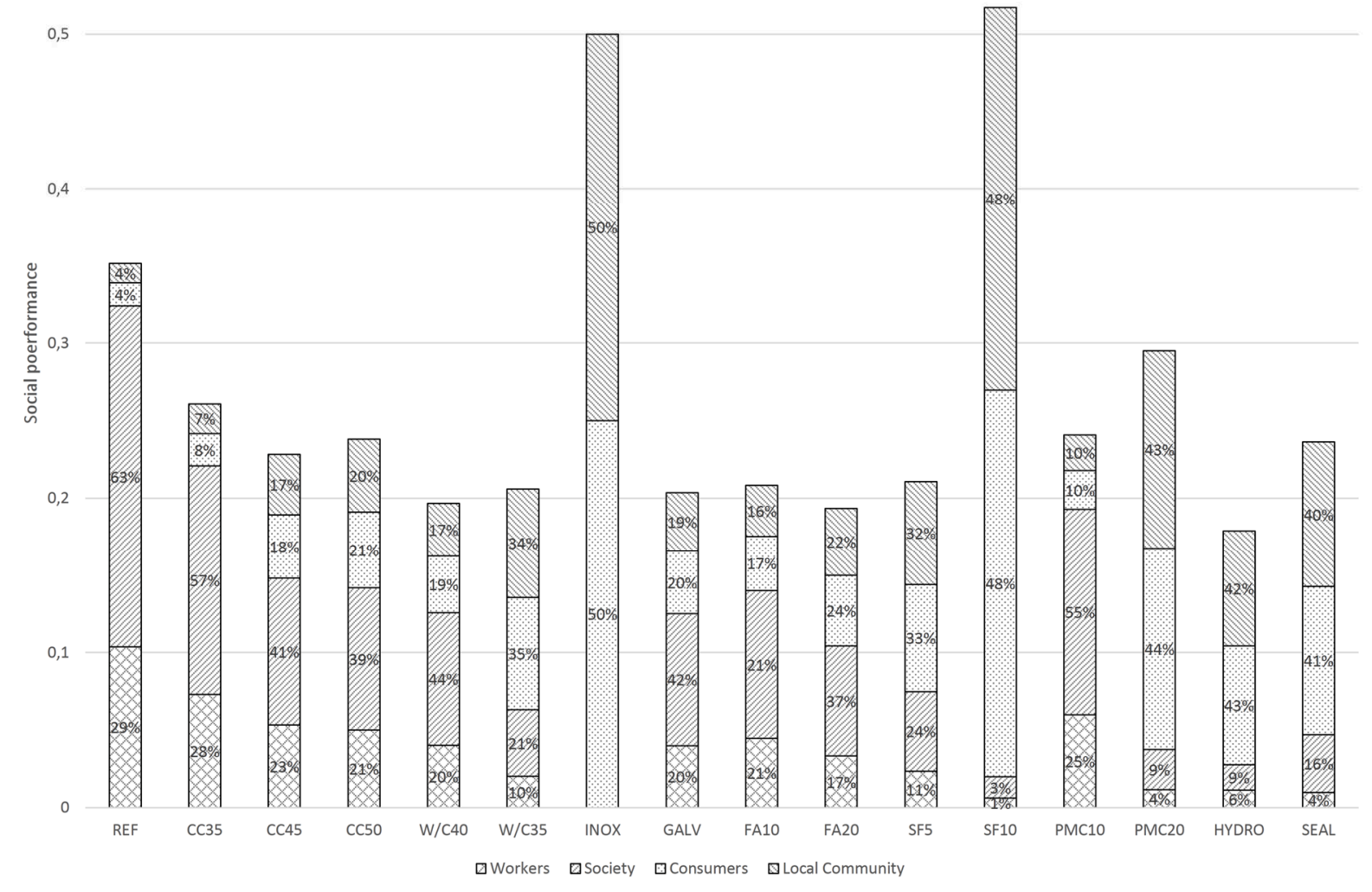

1

2 Fig. 4. Social performance of the alternative designs during the operation and maintenance stage

3 
0,600

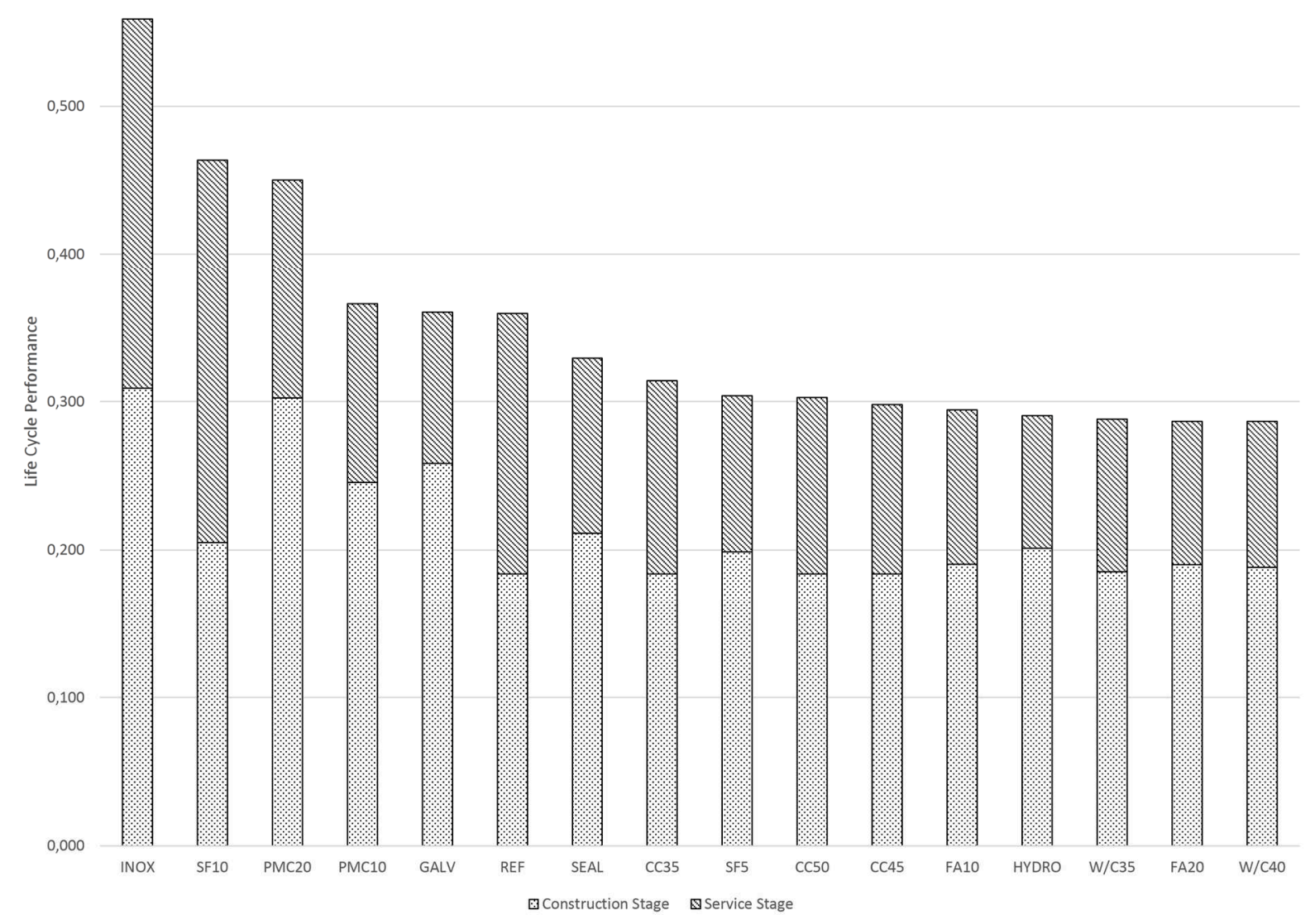

1

2 Fig. 5. Social performance scores after the life cycle assessment

3 


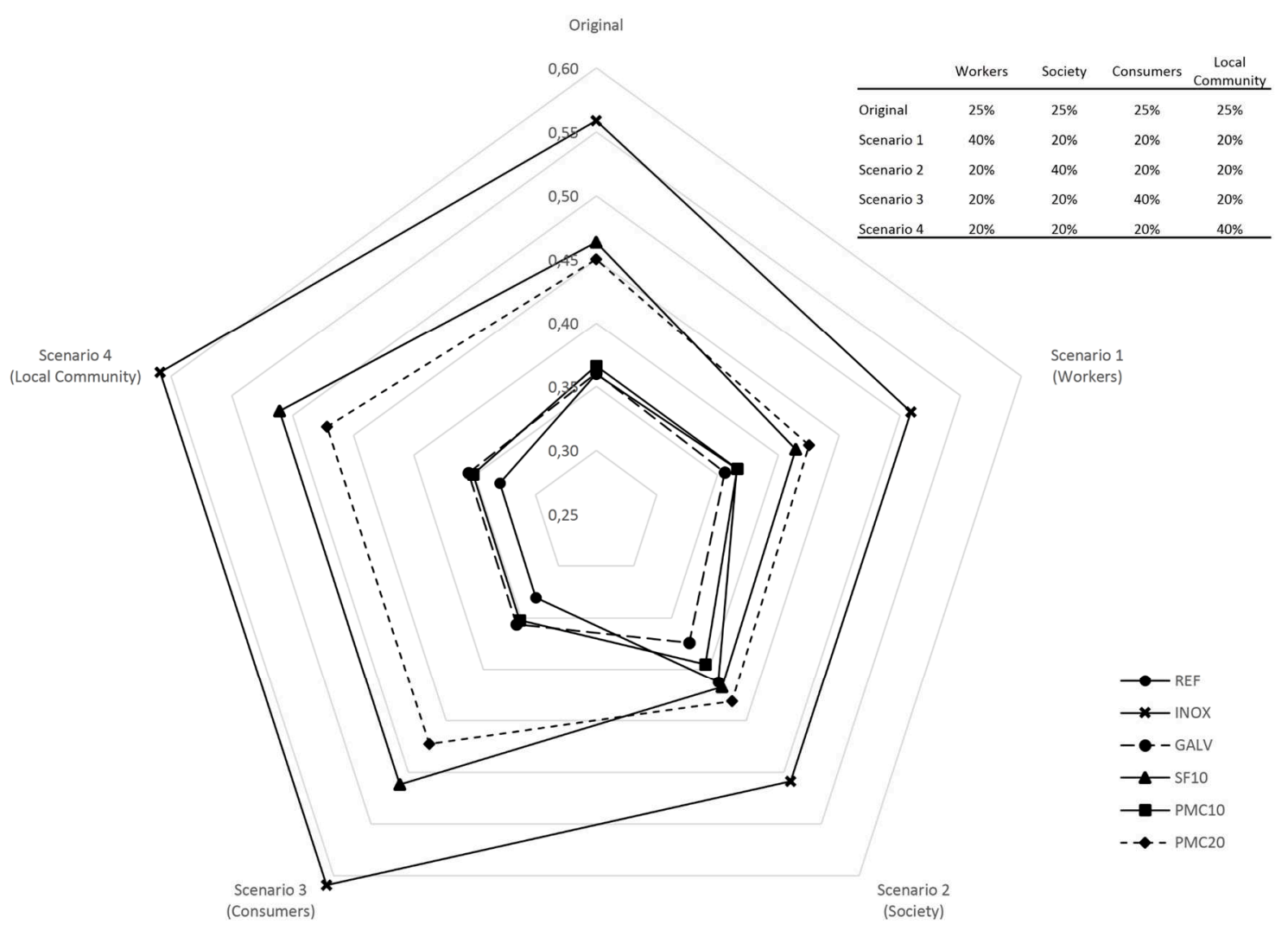

2 Fig. 6. Sensitivity of the results under different weighting scenarios

\section{List of Tables}

5

6 Table 1.Concrete mixes and mechanical properties considered in the alternative designs

7 Table 2. Inventory data on the social context of the different production locations

8 Table 3.Performance values considered for the different processes

9 Table 4.Economic flows per output unit

10 Table 5. Social indicators for the subcategories considered in the study

11 Table 6. Durability characterization parameters of the analyzed designs

12 Table 7.Inventory data expected values on the social context of the different production locations

13 Table 8. Social life cycle performance results ILCA of the analyzed designs

14 Table 9. Sensitivity analysis on weighting factors 
Table 1

Concrete mixes and mechanical properties considered in the alternative designs

\begin{tabular}{lcccccccccc}
\hline & $\begin{array}{c}\text { Cement } \\
\left(\mathrm{kg} / \mathrm{m}^{3}\right)\end{array}$ & $\begin{array}{c}\text { Water } \\
\left(1 / \mathrm{m}^{3}\right)\end{array}$ & $\begin{array}{c}\text { Sand } \\
\left(\mathrm{kg} / \mathrm{m}^{3}\right)\end{array}$ & $\begin{array}{c}\text { Gravel } \\
\left(\mathrm{kg} / \mathrm{m}^{3}\right)\end{array}$ & $\begin{array}{c}\text { Fly Ash } \\
\left(\mathrm{kg} / \mathrm{m}^{3}\right)\end{array}$ & $\begin{array}{c}\text { Silica } \\
\text { Fume } \\
\left(\mathrm{kg} / \mathrm{m}^{3}\right)\end{array}$ & $\begin{array}{c}\text { SBR } \\
\left(\mathrm{kg} / \mathrm{m}^{3}\right)\end{array}$ & $\begin{array}{c}\text { Superplastiziser } \\
\left(\mathrm{kg} / \mathrm{m}^{3}\right)\end{array}$ & $\begin{array}{c}\mathrm{E}_{\mathrm{c}} \\
(\mathrm{Gpa})\end{array}$ & $\begin{array}{c}\mathrm{f}_{\mathrm{cm}} \\
(\mathrm{Mpa})\end{array}$ \\
\hline REF $^{\mathrm{a}}$ & 485.6 & 218.5 & 827.9 & 926.7 & - & - & - & - & 29 & 40 \\
W/C40 & 500 & 200 & 844.1 & 948.0 & - & - & - & 7.5 & 30 & 47 \\
W/C35 & 500 & 175 & 882.8 & 976.7 & - & - & - & 10 & 32 & 55 \\
FA10 & 471 & 218.5 & 798.3 & 926.7 & 48.6 & - & - & - & 29 & 40 \\
FA20 & 456.4 & 218.5 & 768.7 & 926.7 & 97.1 & - & - & - & 29 & 40 \\
SF5 & 437 & 218.5 & 849.1 & 926.7 & - & 24.3 & - & - & 29 & 40 \\
SF10 & 388.4 & 218.5 & 870.2 & 926.7 & - & 48.6 & - & - & 29 & 40 \\
PMC10 & 485.6 & 218.5 & 827.9 & 926.7 & - & - & 48.6 & - & 29 & 50 \\
PMC20 & 485.6 & 218.5 & 827.9 & 926.7 & - & - & 97.1 & - & 29 & 50 \\
\hline Notes: & & & & & & & & & &
\end{tabular}

Notes:
a This mix is also considered in alternatives CC35, CC45, CC50, INOX, GALV, HYDRO and SEAL 
Table 2

Inventory data on the social context of the different production locations

\begin{tabular}{|c|c|c|c|c|c|}
\hline & Pontevedra & A Coruña & Vizcaya & Madrid & Guadalajara \\
\hline \multicolumn{6}{|c|}{ Background data on Unemployment and gender discrimination: } \\
\hline Unemployment rate $(\%)$ & 19 & 14.4 & 12.5 & 13 & 15.4 \\
\hline $\begin{array}{l}\text { Maximum and minimum } \\
\text { national unemployment (\%) }\end{array}$ & {$[8.2-30.8]$} & {$[8.2-30.8]$} & {$[8.2-30.8]$} & {$[8.2-30.8]$} & {$[8.2-30.8]$} \\
\hline Men unemployment (\%) & 18.5 & 13.6 & 12.3 & 12.8 & 13.1 \\
\hline Women unemployment (\%) & 19.5 & 18.2 & 12.9 & 13.3 & 18.2 \\
\hline $\begin{array}{l}\text { Mean region unemployment } \\
(\%)\end{array}$ & 18.99 & 14.42 & 12.54 & 13.04 & 15.43 \\
\hline \multicolumn{6}{|c|}{ Background data on Fair Salary and gender discrimination: } \\
\hline Salary $\left(\times 10^{3} € /\right.$ year $)$ & $\begin{array}{l}14.63^{\mathrm{a}} \\
20.61^{\mathrm{b}}\end{array}$ & $20.61^{\mathrm{a}}$ & $29.06^{\mathrm{a}}$ & $27.91^{\mathrm{a}}$ & $25.06^{\mathrm{a}}$ \\
\hline $\begin{array}{l}\text { Maximum national salary } \\
\left(\mathrm{x} 10^{3} € / \text { year }\right)\end{array}$ & $21.61^{\mathrm{b}}$ & \multirow{2}{*}{\multicolumn{4}{|c|}{$29.065^{\mathrm{a}}$}} \\
\hline $\begin{array}{l}\text { National living wage } \\
\left(\mathrm{x} 10^{3} € / \text { year }\right)\end{array}$ & & & & & \\
\hline Men salary $\left(x 10^{3} € /\right.$ year $)$ & 19.64 & 21.78 & 29.34 & 27.66 & 22.19 \\
\hline Women salary $\left(\mathrm{x} 10^{3} € /\right.$ year $)$ & 14.87 & 16.59 & 20.88 & 20.88 & 16.33 \\
\hline $\begin{array}{l}\text { Mean region salary }\left(\mathrm{x} 10^{3} € / \text { year }\right. \\
\text { ) }\end{array}$ & 17.37 & 19.23 & 25.50 & 25.50 & 19.64 \\
\hline \multicolumn{6}{|l|}{ Background data on Health and Safety: } \\
\hline $\begin{array}{l}\text { Accident rate (accidents/1.000 } \\
\text { employees) }\end{array}$ & $\begin{array}{l}73^{\mathrm{b}} \\
55^{\mathrm{c}}\end{array}$ & $\begin{array}{l}72^{\mathrm{d}} \\
57^{\mathrm{c}}\end{array}$ & $75^{\mathrm{d}}$ & $27^{\mathrm{e}}$ & $50^{\mathrm{e}}$ \\
\hline $\begin{array}{l}\text { Maximum and minimum } \\
\text { national accident rates } \\
\text { (accidents } / 1.000 \text { employees) }\end{array}$ & $\begin{array}{l}{[69-126]^{\mathrm{b}}} \\
{[47-86]^{\mathrm{c}}}\end{array}$ & $\begin{array}{c}{[59-109]^{\mathrm{d}}} \\
{[47-86]^{\mathrm{c}}}\end{array}$ & {$[59-109]^{\mathrm{d}}$} & {$[27-50]^{e}$} & {$[27-50]^{\mathrm{e}}$} \\
\hline \multicolumn{6}{|c|}{ Background data on Regional economy: } \\
\hline $\begin{array}{l}\text { Gross Domestic Product ( } \times 10^{6} \\
€)\end{array}$ & $\begin{array}{l}3157^{\mathrm{a}} \\
1142^{\mathrm{b}}\end{array}$ & $2588^{\mathrm{a}}$ & $5030^{\mathrm{a}}$ & $13571^{\mathrm{a}}$ & $934^{\mathrm{a}}$ \\
\hline $\begin{array}{l}\text { Maximum and minimum } \\
\text { national GDP }\left(\times 10^{6} €\right)\end{array}$ & $\begin{array}{l}{[14-24490]^{\mathrm{a}}} \\
{[64-7901]^{\mathrm{b}}}\end{array}$ & {$[14-24490]^{\mathrm{a}}$} & {$[14-24490]^{\mathrm{a}}$} & {$[14-24490]^{\mathrm{a}}$} & {$[14-24490]^{\mathrm{a}}$} \\
\hline
\end{tabular}

Notes:

Data in the present table has been collected from Spanish National Statistics Institute and Spanish Tax Office databases

${ }^{\mathrm{a}}$ Industry sector; ${ }^{\mathrm{b}}$ Construction sector; ${ }^{\mathrm{c}}$ Extraction industry; ${ }^{\mathrm{d}}$ Metallurgic industry; ${ }^{\mathrm{e}}$ Chemical industry 
Table 3

Performance values considered for the different processes

\begin{tabular}{lrl}
\hline Material Production & & \\
\hline Carbon steel & 0.4136 & $\mathrm{~h} / \mathrm{tn}$ \\
Galvanized steel & 0.4136 & $\mathrm{~h} / \mathrm{tn}$ \\
Stainless steel & 4.9 & $\mathrm{~h} / \mathrm{tn}$ \\
Cement & $0.165 \mathrm{~h} / \mathrm{tn}$ \\
Aggregate extraction & $0.1925 \mathrm{~h} / \mathrm{tn}$ \\
Concrete production & $0.18 \mathrm{~h} / \mathrm{tn}$ \\
Hydrophobic treatment production & $0.045 \mathrm{~h} / \mathrm{m}^{3}$ \\
Sealant treatment production & $0.069 \mathrm{~h} / \mathrm{m}^{3}$ \\
Polymer production & $0.0286 \mathrm{~h} / 1$ \\
Construction activities & & \\
\hline Concreting & $0.35 \mathrm{~h} / \mathrm{m}^{3}$ \\
Steel disposal & $0.024 \mathrm{~h} / \mathrm{kg}$ \\
Surface treatment & $0.11 \mathrm{~h} / \mathrm{m}^{2}$ \\
Concrete cover demolition ${ }^{\mathrm{a}}$ & $0.27-0.405 \mathrm{~h} / \mathrm{m}^{2}$ \\
Steel surface treatment & $0.12 \mathrm{~h} / \mathrm{m}^{2}$ \\
Cover repair & $0.84-1.4 \mathrm{~h} / \mathrm{m}^{2}$ \\
\hline
\end{tabular}

Notes:

${ }^{\text {a }}$ For $30 \mathrm{~mm}$ and $50 \mathrm{~mm}$ cover, respectively. Intermediate results are obtained by linear interpolation.

1

2 
Table 4

Economic flows per output unit

\begin{tabular}{|c|c|c|c|c|c|c|c|c|}
\hline & $\begin{array}{c}\text { Steel } \\
\text { Production }\end{array}$ & $\begin{array}{l}\text { Cement } \\
\text { Production }\end{array}$ & $\begin{array}{c}\text { Concre } \\
\text { te } \\
\text { Product } \\
\text { ion } \\
\end{array}$ & $\begin{array}{c}\text { Additio } \\
n \\
\text { Product } \\
\text { ion }\end{array}$ & $\begin{array}{c}\text { Surface Treatment } \\
\text { Production }\end{array}$ & $\begin{array}{l}\text { Construction and } \\
\text { installation }\end{array}$ & $\begin{array}{l}\text { TOT } \\
\text { AL }\end{array}$ & \\
\hline $\begin{array}{l}\text { HA-30 (reference } \\
\text { concrete) }\end{array}$ & 0.00 & 42.62 & 26.93 & 0.00 & 0.00 & 21.62 & 91.18 & $\begin{array}{l}€ / \\
\mathrm{m}^{3}\end{array}$ \\
\hline HA-30 $(w / c=0.4)$ & 0.00 & 43.89 & 37.81 & 0.00 & 0.00 & 24.33 & $\begin{array}{c}106.0 \\
3\end{array}$ & $\begin{array}{l}€ / \\
\mathrm{m}^{3}\end{array}$ \\
\hline HA-30 $(\mathrm{w} / \mathrm{c}=0.35)$ & 0.00 & 43.89 & 42.24 & 0.00 & 0.00 & 27.04 & $\begin{array}{c}113.1 \\
7\end{array}$ & $\begin{array}{l}€ / \\
\mathrm{m}^{3}\end{array}$ \\
\hline $\begin{array}{l}\text { HA- } 30+10 \% \text { fly } \\
\text { ash }\end{array}$ & 0.00 & 62.09 & 28.37 & 0.00 & 0.00 & 21.62 & $\begin{array}{c}112.0 \\
8\end{array}$ & $\begin{array}{l}€ / \\
\mathrm{m}^{3}\end{array}$ \\
\hline $\begin{array}{l}\text { HA- } 30+20 \% \text { fly } \\
\text { ash }\end{array}$ & 0.00 & 60.16 & 29.80 & 0.00 & 0.00 & 21.62 & $\begin{array}{c}111.5 \\
8\end{array}$ & $\begin{array}{l}€ / \\
\mathrm{m}^{3}\end{array}$ \\
\hline $\begin{array}{l}\text { HA-30 +5\% silica } \\
\text { fume }\end{array}$ & 0.00 & 57.61 & 60.95 & 0.00 & 0.00 & 21.62 & $\begin{array}{c}140.1 \\
7\end{array}$ & $\begin{array}{l}€ / \\
\mathrm{m}^{3}\end{array}$ \\
\hline $\begin{array}{l}\text { HA- } 30+10 \% \text { silica } \\
\text { fume }\end{array}$ & 0.00 & 51.20 & 88.94 & 0.00 & 0.00 & 21.62 & $\begin{array}{c}161.7 \\
6\end{array}$ & $\begin{array}{l}€ / \\
\mathrm{m}^{3}\end{array}$ \\
\hline $\begin{array}{l}\text { HA- } 30+10 \% \\
\text { polymers }\end{array}$ & 0.00 & 64.01 & 26.93 & 240.98 & 0.00 & 21.62 & $\begin{array}{c}353.5 \\
5\end{array}$ & $\begin{array}{l}€ / \\
\mathrm{m}^{3}\end{array}$ \\
\hline $\begin{array}{l}\text { HA-30 }+20 \% \\
\text { polymers }\end{array}$ & 0.00 & 64.01 & 26.93 & 481.47 & 0.00 & 21.62 & $\begin{array}{c}594.0 \\
4\end{array}$ & $\begin{array}{l}€ / \\
\mathrm{m}^{3}\end{array}$ \\
\hline Carbon steel & 0.86 & 0.00 & 0.00 & 0.00 & 0.00 & 0.38 & 1.24 & $€ / \mathrm{k}$ \\
\hline Stainless steel & 4.86 & 0.00 & 0.00 & 0.00 & 0.00 & 0.38 & 5.24 & $€ / \mathrm{k}$ \\
\hline Galvanized steel & 3.24 & 0.00 & 0.00 & 0.00 & 0.00 & 0.38 & 3.62 & $€ / \mathrm{k}$ \\
\hline $\begin{array}{l}\text { Hydrophobic } \\
\text { treatment }\end{array}$ & 0.00 & 0.00 & 0.00 & 0.00 & 4.10 & 1.62 & 5.72 & $€ /$ \\
\hline Sealant treatment & 0.00 & 0.00 & 0.00 & 0.00 & 14.13 & 1.62 & 15.75 & $\begin{array}{l}€ / \\
\mathrm{m}^{2}\end{array}$ \\
\hline
\end{tabular}

1 
Table 5

Social indicators for the subcategories considered in the study

\begin{tabular}{|c|c|c|c|}
\hline Category " $j$ " & Subcategory " $i$ " & Transference Function & Reference \\
\hline \multirow[t]{6}{*}{ Workers } & $\begin{array}{l}\text { Local } \\
\text { Employment }\end{array}$ & $X_{\text {local empl. }}^{\text {activity }}=\frac{u r-U r_{\min }}{U r_{\max }-U r_{\min }}$ & \\
\hline & & $\begin{array}{l}\mathrm{ur}=\text { unemployment rate at the activity location } \\
\mathrm{Ur}_{\min }=\text { minimum national unemployment rate } \\
\mathrm{Ur}_{\max }=\text { maximum national unemployment rate }\end{array}$ & $\begin{array}{l}\text { OECD, 2008; } \\
\text { Sierra et al., } \\
\quad 2017 \text { a }\end{array}$ \\
\hline & $\begin{array}{c}\text { Gender } \\
\text { Discrimination }\end{array}$ & $\begin{array}{l}\quad X_{\text {gender disc. }}^{\text {activity }}=0.5 \cdot \min \left\{1-\left|\frac{U r_{m}}{U r_{\text {mean }}}-1\right| ; 1-\left|\frac{U r_{w}}{U r_{\text {mean }}}-1\right|\right\}+0.5 \\
\qquad \cdot \min \left\{1-\left|\frac{S_{m}}{S_{\text {mean }}}-1\right| ; 1-\left|\frac{S_{w}}{S_{\text {mean }}}-1\right|\right\} \\
\mathrm{Ur}_{\mathrm{m}}=\text { men's unemployment rate at the activity location } \\
\mathrm{Ur}_{\mathrm{w}}=\text { women's unemployment rate at the activity location } \\
\mathrm{Ur}_{\text {mean }}=\text { mean unemployment rate at the activity location } \\
\mathrm{S}_{\mathrm{m}}=\text { men's mean salary for the specific activity at the activity location } \\
\mathrm{S}_{\mathrm{w}}=\text { women's mean salary for the specific activity at the activity location } \\
\mathrm{S}_{\text {mean }}=\text { mean salary for the specific activity at the activity location }\end{array}$ & $\begin{array}{l}\text { European } \\
\text { Institute for } \\
\text { Gender } \\
\text { Equality, } 2015\end{array}$ \\
\hline & Workers Safety & $X_{\text {safety }}^{\text {activity }}=1-\frac{a r-A r_{\min }}{A r_{\max }-A r_{\min }}$ & \\
\hline & & $\begin{array}{l}\mathrm{ar}=\text { accident rate for the specific activity at the activity location } \\
\mathrm{Ar}_{\min }=\text { minimum national accident rate for the specific activity } \\
\mathrm{Ar}_{\max }=\text { maximum national accident rate for the specific activity }\end{array}$ & $\begin{array}{l}\text { OECD, 2008; } \\
\text { Sierra et al., } \\
\quad 2017 \text { a }\end{array}$ \\
\hline & Fair Salary & $\begin{array}{l}\qquad X_{\text {salary }}^{\text {ctivity }}=\frac{s-S_{\min }}{S_{\max }-S_{\min }} \\
\mathrm{s}=\text { mean salary for the specific activity at the activity location } \\
\mathrm{S}_{\min }=\text { Lnational living wage } \\
\mathrm{S}_{\max }=\text { maximum national salary for the specific activity }\end{array}$ & OECD, 2008 \\
\hline \multirow[t]{2}{*}{ Society } & $\begin{array}{l}\text { Economic } \\
\text { Development }\end{array}$ & $X_{\text {local economy }}^{\text {activity }}=\left(1-\frac{g d p-G D P_{\min }}{G D P_{\max }-G D P_{\min }}\right)$ & \\
\hline & & $\begin{array}{l}\mathrm{gdp}=\text { Gross Domestic Product at the activity location } \\
\mathrm{GDP}_{\min }=\text { Minimum national Gross Domestic Product } \\
\mathrm{GDP}_{\max }=\text { Maximum national Gross Domestic Product }\end{array}$ & OECD, 2008 \\
\hline \multirow[t]{4}{*}{ Consumer } & Accesibility & $X_{\text {accesibility }}^{\text {maintenance }}=\frac{\left(T_{S L}-\sum t_{m}\right) \cdot 1+\sum t_{m} \cdot a}{T_{S L}}$ & \\
\hline & & $\begin{array}{l}\mathrm{T}_{\mathrm{SL}}=\text { bridge service life } \\
\Sigma \mathrm{t}_{\mathrm{m}}=\text { total time that the bridge is under maintenance } \\
\mathrm{a}=\text { bridge availability, which is the ratio between traffic speed under maintenance and } \\
\text { normal operation circumstances }\end{array}$ & $\begin{array}{l}\text { Dette and } \\
\text { Sigrist, } 2011\end{array}$ \\
\hline & User's Safety & $X_{\text {user's safety }}^{\text {maintenance }}=1-\frac{l}{L_{\text {tot }}} \cdot \frac{\sum t_{m}}{T_{S L}} \cdot \frac{v}{V_{\text {norm }}}$ & \\
\hline & & $\begin{array}{l}\text { l = length of the maintenance work zone } \\
\mathrm{L}_{\mathrm{tot}}=\text { bridge total length } \\
\mathrm{T}_{\mathrm{SL}}=\text { bridge service life } \\
\Sigma \mathrm{t}_{\mathrm{m}}=\text { total time that the bridge is under maintenance } \\
\mathrm{v}=\text { traffic speed under maintenance operations along the work zone } \\
\mathrm{V}_{\text {norm }}=\text { traffic speed under normal operation conditions }\end{array}$ & $\begin{array}{l}\text { Ozturk et al., } \\
\quad 2013\end{array}$ \\
\hline \multirow[t]{2}{*}{$\begin{array}{l}\text { Local } \\
\text { Community }\end{array}$} & Public Opinion & $X_{\text {public opinion }}^{\text {maintenance }}=1-R T U A=1-\frac{\sum t_{m}}{T_{S L}}$ & \\
\hline & & $\begin{array}{l}\text { RTUA = relative time of unsatisfactory appearance } \\
\mathrm{T}_{\mathrm{SL}}=\text { bridge service life } \\
\Sigma \mathrm{t}_{\mathrm{m}}=\text { total time that the bridge is under maintenance }\end{array}$ & $\begin{array}{l}\text { Dette and } \\
\text { Sigrist, } 2011\end{array}$ \\
\hline
\end{tabular}


Table 6

Durability characterization parameters of the analyzed designs

\begin{tabular}{|c|c|c|c|c|c|c|c|c|}
\hline \multirow{2}{*}{$\begin{array}{l}\text { Design } \\
\text { alternative }\end{array}$} & \multirow{2}{*}{ Reference } & \multicolumn{2}{|c|}{$\begin{array}{c}\mathrm{D}_{0}\left(\mathrm{x} 10^{-12}\right. \\
\left.\mathrm{m}^{2} / \mathrm{s}\right)\end{array}$} & \multicolumn{2}{|c|}{$\mathrm{C}_{\text {crít }}(\%)$} & \multicolumn{2}{|c|}{$\mathrm{r}_{\mathrm{x}}(\mathrm{mm})$} & \multirow{2}{*}{$\begin{array}{l}\text { Mea } \\
n \\
\text { time } \\
\text { to } \\
\text { failu } \\
\text { re } \\
\text { (yea } \\
\text { rs) }\end{array}$} \\
\hline & & $\begin{array}{c}\mathrm{Me} \\
\text { an }\end{array}$ & $\begin{array}{l}\text { Std. } \\
\text { Dev. }\end{array}$ & $\begin{array}{c}\mathrm{Me} \\
\text { an }\end{array}$ & $\begin{array}{l}\text { Std. } \\
\text { Dev. }\end{array}$ & $\begin{array}{c}\mathrm{Me} \\
\text { an }\end{array}$ & $\begin{array}{l}\text { Std. } \\
\text { Dev. }\end{array}$ & \\
\hline REF & \multirow{6}{*}{$\begin{array}{l}\text { Cheewaket et al., 2014; Nokken et al., 2006; Vedalakshmi et } \\
\text { al., 2009; Xi et al., } 1999\end{array}$} & 10 & 1.1 & 0.6 & 0.1 & 30 & 1.5 & 4 \\
\hline CC35 & & 10 & 1.1 & 0.6 & 0.1 & 35 & 1.75 & 5 \\
\hline $\mathrm{CC} 45$ & & 10 & 1.1 & 0.6 & 0.1 & 45 & 2.25 & 9 \\
\hline CC50 & & 10 & 1.1 & 0.6 & 0.1 & 50 & 2.5 & 11 \\
\hline \multirow{2}{*}{$\begin{array}{l}\mathrm{W} / \mathrm{C} 40 \\
\mathrm{~W} / \mathrm{C} 35\end{array}$} & & $\begin{array}{c}6.1 \\
5\end{array}$ & 0.51 & 0.6 & 0.1 & 30 & 1.5 & 8 \\
\hline & & $\begin{array}{c}4.3 \\
2\end{array}$ & 0.33 & 0.6 & 0.1 & 30 & 1.5 & 14 \\
\hline \multirow{2}{*}{$\begin{array}{l}\text { INOX } \\
\text { GALV }\end{array}$} & Bertolini et al., 1996 & 10 & 1.1 & 5 & 0.94 & 30 & 1.5 & - \\
\hline & Darwin et al., 2009 & 10 & 1.1 & 1.2 & 0.21 & 30 & 1.5 & 9 \\
\hline PMC10 & \multirow{2}{*}{ Ohama, 1995; Yang et al., 2009} & $\begin{array}{c}7.3 \\
2\end{array}$ & 0.66 & 0.6 & 0.1 & 30 & 1.5 & 8 \\
\hline PMC20 & & $\begin{array}{c}3.0 \\
4\end{array}$ & 0.24 & 0.6 & 0.1 & 30 & 1.5 & 10 \\
\hline \multirow{2}{*}{$\begin{array}{l}\text { SF5 } \\
\text { SF10 }\end{array}$} & \multirow{2}{*}{ Frederiksen, 2000} & $\begin{array}{c}3.3 \\
1\end{array}$ & 0.25 & $\begin{array}{c}0.3 \\
8\end{array}$ & 0.06 & 30 & 1.5 & 14 \\
\hline & & $\begin{array}{c}1.3 \\
8\end{array}$ & 0.17 & $\begin{array}{c}0.2 \\
2\end{array}$ & 0.03 & 30 & 1.5 & 34 \\
\hline \multirow{2}{*}{$\begin{array}{l}\text { FA10 } \\
\text { FA20 }\end{array}$} & \multirow{2}{*}{ Otsuki et al., 2014} & $\begin{array}{c}6.1 \\
6\end{array}$ & 0.51 & 0.6 & 0.1 & 30 & 1.5 & 6 \\
\hline & & $\begin{array}{c}5.2 \\
3\end{array}$ & 0.41 & 0.6 & 0.1 & 30 & 1.5 & 25 \\
\hline \multirow{2}{*}{$\begin{array}{l}\text { HYDRO } \\
\text { SEAL }\end{array}$} & Zhang and Buenfeld, 2000 & $\begin{array}{c}7.7 \\
3\end{array}$ & 0.72 & 0.6 & 0.1 & 30 & 1.5 & $5^{\mathrm{a}}$ \\
\hline & Medeiros et al., 2012 & $\begin{array}{c}4.8 \\
7\end{array}$ & 0.37 & 0.6 & 0.1 & 30 & 1.5 & $5^{\mathrm{a}}$ \\
\hline
\end{tabular}

Notes:

${ }^{a}$ In the present study, the service life of surface treatments (HYDRO and SEAL) is limited to 5 years according to

manufacturer specifications, as the durability performance of these treatments is very sensitive to cracks in the concrete cover 
Table 7

Inventory data expected values on the social context of the different production locations

Background data on Unemployment and gender discrimination:
Unemployment rate $(\%)$

16.8

$(7.5-25.8)$

Maximum national unemployment (\%)

Minimum national unemployment (\%)

Men unemployment (\%)

Women unemployment (\%)

Mean region unemployment (\%)

A Coruña

13.9

$(6.8-21.7)$
Vizcaya

12.5

(6.6 - 18.9)

28.98

(13.53-43.23)

7.74

(2.1 - 14.31)

11.8

$(4.9-19.8)$

13.4

$(7.7-18.7)$

12.5

(6.6 - 18.9)

(7.5 - 25.8)

$(8.5-22.2)$

13.9

(6.7 - 21.7)

19.6

$(18-20.6)$

$(18-20.6)^{\mathrm{a}}$

14.3

$(13.1-14.9)^{\mathrm{b}}$

Maximum national salary

(x10 $10^{3} € /$ year)

National living wage

(x10 $€$ /year)

Men salary (x10€/year)

Women salary (x10³ $€$ /year)

Mean region salary (x10³ $€$ /year)

Background data on Health and Safety:

Accident rate (accidents/1.000

employees)

Maximum national accident rate (accidents/1.000 employees)

Minimum national accident rate (accidents/1.000 employees)

Background data on Regional economy:

Gross Domestic Product $\left(\times 10^{6} €\right)$

Maximum national GDP (x10 $€$ )

Minimum national GDP (x10 6 )

\section{(13.1 -14.9$)^{b}$}

(1) 
Table 8

Social life cycle performance results ILCA of the analyzed designs

\begin{tabular}{cccccc}
\hline & IConstruction Stage & IService Stage & $I_{L C A}$ & \multicolumn{2}{c}{$\begin{array}{c}\text { ILCA Confidence Intervals } \\
{[5 \%-95 \%]}\end{array}$} \\
\hline REF & 0.368 & 0.351 & 0.360 & 0.347 & 0.372 \\
CC35 & 0.368 & 0.261 & 0.314 & 0.305 & 0.323 \\
CC45 & 0.368 & 0.228 & 0.298 & 0.292 & 0.304 \\
CC50 & 0.368 & 0.238 & 0.303 & 0.297 & 0.309 \\
W/C40 & 0.377 & 0.197 & 0.287 & 0.282 & 0.292 \\
W/C35 & 0.371 & 0.206 & 0.288 & 0.286 & 0.291 \\
INOX & 0.618 & 0.500 & 0.559 & 0.559 & 0.559 \\
GALV & 0.517 & 0.204 & 0.360 & 0.356 & 0.365 \\
FA10 & 0.381 & 0.208 & 0.294 & 0.289 & 0.300 \\
FA20 & 0.380 & 0.193 & 0.287 & 0.283 & 0.291 \\
SF5 & 0.397 & 0.211 & 0.304 & 0.301 & 0.307 \\
SF10 & 0.410 & 0.517 & 0.464 & 0.463 & 0.464 \\
PMC10 & 0.491 & 0.241 & 0.366 & 0.359 & 0.373 \\
PMC20 & 0.605 & 0.295 & 0.450 & 0.449 & 0.451 \\
HYDRO & 0.402 & 0.179 & 0.291 & 0.290 & 0.291 \\
SEAL & 0.423 & 0.236 & 0.329 & 0.329 & 0.330 \\
\hline
\end{tabular}

1 
Table 9

Sensitivity analysis on weighting factors

\begin{tabular}{cccc}
\hline & Scenario $1^{\mathrm{a}}$ & Scenario $^{\mathrm{b}}$ & ${\text { Scenario } 3^{\mathrm{c}}}^{\mathrm{a}}$ \\
\hline REF & 0.360 & 0.329 & 0.383 \\
CC35 & 0.314 & 0.301 & 0.343 \\
CC45 & 0.298 & 0.296 & 0.309 \\
CC50 & 0.303 & 0.301 & 0.312 \\
W/C40 & 0.287 & 0.284 & 0.300 \\
W/C35 & 0.288 & 0.297 & 0.283 \\
INOX & 0.559 & 0.609 & 0.509 \\
GALV & 0.360 & 0.356 & 0.370 \\
FA10 & 0.294 & 0.287 & 0.304 \\
FA20 & 0.287 & 0.287 & 0.286 \\
SF5 & 0.304 & 0.311 & 0.298 \\
SF10 & 0.464 & 0.512 & 0.416 \\
PMC10 & 0.366 & 0.351 & 0.390 \\
PMC20 & 0.450 & 0.510 & 0.453 \\
HYDRO & 0.291 & 0.325 & 0.291 \\
SEAL & 0.329 & 0.345 & 0.317 \\
\hline
\end{tabular}

Notes:

${ }^{a}$ Scenario 1 is based on equal weighting of the different stakeholder categories (25\%). It is the scenario considered in the present study.

${ }^{\mathrm{b}}$ Scenario 2 assigned weights: Workers (20\%), Society (20\%), Consumers (30\%), Local Community $(30 \%)$

${ }^{c}$ Scenario 3 assigned weights: Workers (30\%), Society (30\%), Consumers (20\%), Local Community (20\%) 